УДК 547.992.3:541.13

\title{
ЭЛЕКТРОХИМИЧЕСКИЕ РЕАКЦИИ ЛИГНИНА (ОБЗОР)
}

\section{() Э.И. Евстигнеев}

\author{
Санкт-Петербургский государственный лесотехнический университет, \\ Институтский пер., 5, Санкт-Петербург, 124021 (Россия), \\ e-mail: edward_evst@mail.ru
}

Рассмотрены реакционная способность и механизмы электрохимических реакций лигнина и модельных соединений при восстановлении и окислении на различных электродах в водных, водно-органических и неводных средах. Обсуждаются прямые и непрямые катодные и анодные реакции, а также автопротонирование в неводных средах и электрокаталитические реакции.

При восстановлении на РКЭ реакционными центрами лигнина являются карбонильные группы различных типов и сопряженные двойные связи. Наиболее представительные в лигнине связи b-O-4 способны к электрохимическому расщеплению при наличии в смежном положении карбонильной группы. В неводных апротонных средах на реакции восстановления лигнина существенное влияние оказывает автопротонирование за счет имеющихся в нем фенольных гидроксильных групп. Непрямое электрохимическое препаративное восстановление, например амальгамами, позволяет проводить деструкцию лигнина до низкомолекулярных соединений. Использование полярографии применительно к лигнину открывает новые возможности анализа функционального состава, а также изучения механизмов химических и электрохимических реакций.

При анодном окислении реакционными центрами лигнина являются ароматические кольца. Наличие в молекуле деполяризатора фенольных гидроксилов облегчает окисление в щелочных средах, однако оно сопровождается реакциями димеризации и полимеризации. В целом процесс окисления развивается по двум направлениям: деструкции до низкомолекулярных соединений, включая $\mathrm{CO}_{2}$, и полимеризации. Максимальная степень деструкции для исследованных препаратов лигнина составляет 50\%.

Лигнин нерастворим в ацетонитриле и кислотах, но, судя по результатам исследования модельных соединений, при окислении в указанных средах можно ожидать глубокой деструкции до ароматических альдегидов, кетонов и кислот, а также алифатических соединений.

Ключевые слова: лигнин, модельные соединения, полярография, вольтамперометрия, препаративный электролиз, электрохимические реакции.

\section{Введение}

Лигнин - второй по распространенности на Земле биополимер, и поэтому он является постоянным объектом фундаментальных и прикладных исследований. Современное состояние знаний о строении, реакционной способности и растворимости лигнина рассмотрено в монографии [1]. Здесь отметим только наблюдающуюся эволюцию взглядов на топологическую структуру этого природного высокомолекулярного соединения от «...природный лигнин представляет собой трехмерный сетчатый полимер» [2, с. 498] к «... его макромолекула разветвлена...» (цитировано по [3, с. 261]) до «...лигнин характеризуется двумя различными типами макромолекул, а именно линейными и ... много более разветвленными» [4]. Существование линейных молекул в низкомолекулярной фракции лигнина эвкалипта доказано экспериментально методом масс-спектрометрии [5].

Являясь полифункциональным, полидисперсным, нерегулярным гетерополимером, лигнин представляет собой достаточно сложный объект для изучения электрохимических реакций. Неслучайно поэтому и в этой области химии лигнина широко используются модельные соединения. Это обеспечивает все преимущества работы с индивидуальными веществами и позволяет оценивать реакционную способность

Евстигнеев Эдуард Иванович - профессор кафедры технологии лесохимических продуктов, химии древесины и физической химии, доктор химических наук, e-mail: edward_evst@mail.ru фрагментов макромолекулы лигнина различного строения и выяснять механизмы протекающих электрохимических реакций. Изучение модельных соединений имеет и самостоятельное значение, по- 
скольку они в основном являются производными фенолов и таким образом полученные результаты обогащают знания в области электрохимии ароматических соединений.

Интересно отметить, что первая в истории полярограмма органического соединения (нитробензола) была записана в 1925 г. профессором химии древесины Шикатой [6], а первая полярограмма лигнина, по-видимому, Канда с соавторами [7] на сельскохозяйственном факультете университета Нагойя. Таким образом, у истоков полярографии органических соединений стояли специалисты, занимавшиеся химией древесины и лигнина.

\section{Катодные реакции}

\section{Восстановление в водной и водно-органической средах}

Полярография лигнина началась с изучения каталитических волн, проявляющихся в аммиачных буферных растворах солей кобальта [7-9]. В соответствии с существующими представлениями [10] каталитические волны водорода вызываются органическими соединениями, способными присоединять водород с образованием ониевых соединений, таких как амины, сульфиды, тиолы и др. Ониевый катион, как правило, обратимо принимает электрон, превращаясь в свободный радикал:

$$
\mathrm{BH}^{+}+\mathrm{e} \rightleftharpoons \mathrm{BH}^{\bullet}
$$

Их бимолекулярное взаимодействие приводит к регенерации непротонированной формы В и выделению молекулы водорода

$$
2 \mathrm{BH} \longrightarrow 2 \mathrm{~B}+\mathrm{H}_{2}
$$

Форма В вновь вступает в реакцию протонирования, и весь цикл повторяется. Величина предельного тока вследствие многократного повторения цикла за время жизни капли капельного электрода в раствоpax с высокой протонодонорной активностью может на несколько порядков превышать гипотетический диффузионный ток, который наблюдался бы при отсутствии регенерации катализатора. Катализатором служит комплекс кобальта с органической молекулой. Предполагается, что повышение каталитической активности тиолов при образовании ими комплексов с $\mathrm{Co}^{2+}$ связано с увеличением на две единицы заряда катализаторов, что должно значительно облегчать перенос электрона на такие частицы.

Результаты работ [7-9] в целом укладываются в эту схему. Как указывают авторы, сульфатный лигнин проявляет каталитическую волну, идентичную волне соединений, содержащих группировки SS и SH. Исследованные модельные соединения с каталитической активностью не обладают, но приобретают ее в результате сульфатной варки, причем те из них, которые первоначально содержали свободный фенольный гидроксил. Тем не менее предполагаемые структуры, ответственные за каталитическую активность, не содержат серосодержащих группировок.
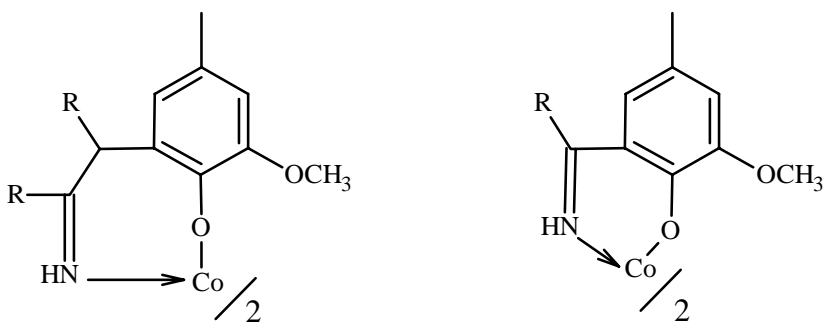

Заметим, что указанные структуры отражают строение продуктов щелочной деструкции лигнина, участвующих в образовании комплекса, а не собственно лигнина.

Потенциально способными к электрохимическому восстановлению в молекуле лигнина являются карбонильные группы различных типов и сопряженные двойные связи. Механизм реакции восстановления ароматических альдегидов и кетонов на ртутном капельном электроде (РКЭ) достаточно хорошо исследован [11].

В кислых водных и водно-органических средах (до рН 5) ароматические альдегиды и кетоны восстанавливаются в две последовательные $1 e$-стадии. Первая из них (в диапазоне от $-0,8$ до $-1,3$ В) соответствует восстановлению протонированной карбонильной группы до кетильного радикала: 


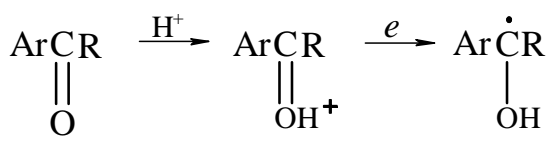

Образовавшиеся в результате реакции (3) кетильные радикалы либо димеризуются в соответствующие пинаконы или гликоли, либо восстанавливаются далее до карбинола:<smiles>[R]C(O)[14CH2][14C](O)[14CH][14C](O)[14CH2]O</smiles>

Вторая стадия восстановления (4) протекает при более отрицательных потенциалах $(-1,3$ В), и при невысоких значениях $\mathrm{pH}$ она часто маскируется током разряда фона. Потенциалы приведены относительно насыщенного каломельного электрода (НКЭ).

В щелочной среде при $\mathrm{pH}>12$ при потенциале -1,5 В наблюдается 1e-волна, которая отражает восстановление непротонированного карбонила. Кроме того, при более отрицательных потенциалах (около 2,0 В) происходит одноэлектронное восстановление анион-радикала до дианиона (уравнение 5). Соответствующая волна лежит при столь отрицательных потенциалах, что обыкновенно перекрывается током разряда фонового электролита.<smiles>[R]O[14CH2][14CH][14C]([R])OC</smiles>

По таким же механизмам восстанавливаются карбонилсодержащие модельные соединения лигнина, исследованные в работах [12-20]. В таблице 1 приведены потенциалы восстановления только для $\mathrm{pH} \geq 12$, поскольку полярографические исследования лигнина проводились преимущественно в щелочных средах. Для пропиофенона и его производных потенциалы приведены при рН 9, так как при более высоких рН волна восстановления перекрывается током разряда фонового электролита.

Данные таблицы 1 показывают, что модельные соединения, содержащие в пара-положении к реакционному центру гидроксильную группу (типичные структуры для растворимых в щелочи лигнинов), имеют $E_{1 / 2}$ от $-1,85$ до - $1,98 \mathrm{~B}$, а волна восстановления 4-гидроксипропиофенона в этих условиях не проявляется. Соединение, содержащее сопряженную двойную связь, изоэвгенол, в щелочной среде также полярографически неактивно [18]. Иными словами, изучение реакций электрохимического восстановления модельных соединений и лигнина в щелочных средах ограничено потенциалом разряда фонового электролита ( -2,0 B).

Таблица 1. Полярографические потенциалы модельных соединений лигнина (pH 12-13)

\begin{tabular}{l|c|c}
\hline \multicolumn{1}{c|}{ Соединение } & $-E_{1 / 2}$, В (отн. НКЭ) & Источник \\
\hline бензальдегид & 1,48 & {$[16]$} \\
4-гидроксибензальдегид & 1,86 & {$[16]$} \\
4-метоксибензальдегид & 1,58 & {$[16]$} \\
3,4-дигидроксибензальдегид & 1,88 & {$[16]$} \\
4-гидрокси- 3-метоксибензальдегид & 1,85 & {$[16]$} \\
2-гидрокси-3-метоксибензальдегид & 1,74 & {$[16]$} \\
2,3-диметоксибензальдегид & 1,35 & {$[16]$} \\
3,4-диметоксибензальдегид & 1,46 & {$[16]$} \\
4-гидрокси- 3,5-диметоксибензальдегид & 1,82 & {$[17]$} \\
ацетофенон & 1,62 & {$[17]$} \\
4-гидроксиацетофенон & 1,98 & {$[17]$} \\
4-гидрокси-3-метоксиацетофенон & 1,95 & {$[17]$} \\
4-гидрокси-3,5-диметоксиацетофенон & 1,94 & {$[15]$} \\
2-гидрокси-3-метоксиацетофенон & 1,73 & {$[15]$} \\
пропиофенон & $1,52 *$ & {$[15]$} \\
4-гидроксипропиофенон & $1,69 *$ & $1,56 *$ \\
2-гидроксипропиофенон & & {$[17]$} \\
\hline
\end{tabular}

* - при рН 9 
В водных растворах гидроксидов натрия и лития лигнин проявляет от 1 до 3 полярографических волн в зависимости от происхождения данного препарата и условий полярографирования [18, 21-27]. Природа этих волн подробно исследована в работе [24]. Методами классической (постояннотоковой), дифференциальной и переменнотоковой полярографии установлено, что число и потенциалы волн зависят прежде всего от концентрации лигнина. Как показало изучение концентрационной и температурной зависимостей предельного тока, а также электрокапиллярных кривых, процесс восстановления осложнен сильной адсорбцией деполяризатора на РКЭ.

При концентрациях, не превышающих 0,2 мг·мл ${ }^{-1}$, классическая полярограмма содержит две волны, причем $E_{1 / 2}$ первой из них составляет в зависимости от концентрации от $-0,88$ до $-0,98$ В, а для второй 1,45-1,50 В. Вторая волна является «ложной», поскольку она отражает процесс десорбции лигнина с РКЭ. При увеличении концентрации лигнина выше 0,2 мг·мл ${ }^{-1}$ появляется и растет еще одна волна, расположенная между указанными волнами с $E_{1 / 2} \sim-1,4$ В, отражающая восстановление лигнина на поверхности РКЭ, полностью покрытой адсорбированными молекулами этого деполяризатора.

В поисках средств подавления адсорбции лигнина на электроде и расширения диапазонов восстановления в работах $[23,25,26]$ методом переменнотоковой полярографии исследованы полярографические характеристики лигнина в смешанном (диоксан : вода $9: 1)$ и апротонном (диметилсульфоксид) растворителях. Полярографические характеристики представлены в таблице 2.

В буферных растворах, приготовленных в смешанном растворителе, определена зависимость потенциала восстановления лигнина от $\mathrm{pH}$. Она оказалась довольно необычной и представляет собой $\mathrm{V}$-образную кривую с минимумом при $\mathrm{pH}$, близким 7. Обычно с увеличением $\mathrm{pH}$ потенциал восстановления смещается в сторону отрицательных значений. Аномальный вид обсуждаемой зависимости для лигнина объясняется наличием в нем развитой системы внутри- и межмолекулярных водородных связей.

В работах $[23,25,26]$ установлено также, что полное устранение адсорбции на РКЭ и наибольшее число волн, отражающих восстановление функциональных групп лигнина, наблюдается в диметилсульфоксиде (ДМСО) на фоне перхлората тетрабутиламмония (ПТБА). В этих условиях диапазон проведения электрохимических реакций расширяется до -3 В, а волны восстановления являются диффузионными, о чем свидетельствуют концентрационные зависимости предельного тока. Подробно полученные результаты обсуждаются в следующем разделе.

Таблица 2. Полярографические характеристики лигнина Пеппера ели в смешанном и апротонном растворителях [23]

\begin{tabular}{l|c|c|c|c|c|c|c|c}
\hline \multicolumn{1}{c|}{ Растворитель } & $-E_{\mathrm{p}}$ & $I_{\mathrm{p}} \cdot 10^{-1}$ & $-E_{\mathrm{p}}$ & $I_{\mathrm{p}} \cdot 10^{-1}$ & $-E_{\mathrm{p}}$ & $I_{\mathrm{p}} \cdot 10^{-1}$ & $-E_{\mathrm{p}}$ & $I_{\mathrm{p}} \cdot 10^{-1}$ \\
\hline Диоксан : вода 9:1 & 1,06 & 0,03 & 1,48 & 0,15 & - & - & - & - \\
Диметилсульфоксид & 1,09 & 0,08 & 1,48 & 0,17 & 2,05 & 0,53 & 2,44 & 0,46 \\
\hline
\end{tabular}

Примечание. $E_{\mathrm{p}}$ - потенциал пика, В отн. НКЭ. $I_{\mathrm{p}}$ - токовая константа, мкА $\cdot \mathrm{M \Gamma}^{-1} \cdot \mathrm{M} \cdot \mathrm{M \Gamma}^{-2 / 3}$.

\section{Восстановление в неводных средах}

В работах [28-34] методами дифференциальной импульсной полярографии (ДИП) и циклической вольтамперометрии (ЦВА) в ДМСО на фоне ПТБА исследованы различные препараты лигнина, а также мономерные и димерные модельные соединения, содержащие основные типы функциональных групп и связей лигнина, потенциально способных к электрохимическому восстановлению.

Карбонилсодержащие соединения. В соответствии с данными литературы [2], лигнин содержит карбонильные группы в $\alpha-, \beta$ - и $\gamma$-положениях боковой цепи фенилпропановых единиц (ФПЕ), а их общее содержание в ЛМР ели составляет 20 карбонильных групп на 100 ФПЕ (20/100 ФПЕ). На долю $\alpha$-СО-групп приходится 7/100 ФПЕ, а на долю $\beta$-СО-групп - 10/100 ФПЕ. $\gamma$-Карбонильные группы (3/100 ФПЕ) входят в структуры типа кониферилового альдегида и будут рассмотрены в разделе, посвященном соединениям, содержащим двойную связь (см. ниже). В продуктах этанолиза и ацидолиза ЛМР ели найдены $\alpha, \beta$-дикарбонильные соединения [2], поэтому они также включены в рассмотрение.

Ароматические альдегиды и кетоны. Модельные соединения лигнина с $\alpha$-карбонильными группами являются производными соответствующих ароматических альдегидов и кетонов. К ним относятся и иссле-

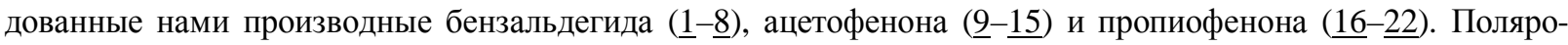
графические характеристики приведены в таблицах 3-5. 


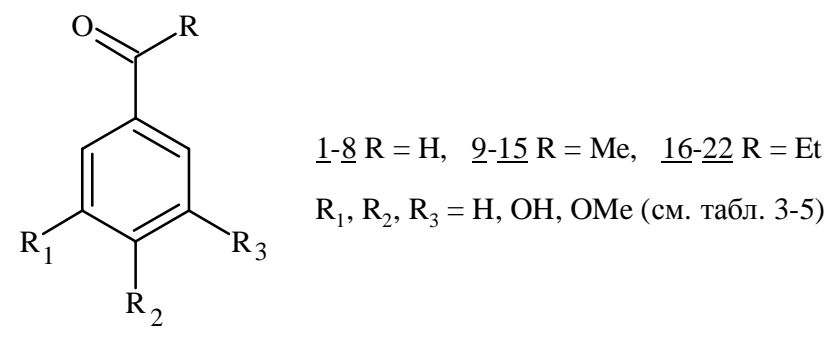

Таблица 3. Полярографические характеристики производных бензальдегида [28]

\begin{tabular}{c|c|c|c|c|c|cc}
\hline Соединение & $\mathrm{R}_{1}$ & $\mathrm{R}_{2}$ & $\mathrm{R}_{3}$ & $-E_{\mathrm{p}}{ }^{1}, \mathrm{~B}$ & $\mathrm{i}_{\mathrm{p}}{ }^{1}, \mu \mathrm{A}$ & $\mathrm{r} *$ \\
\hline$\underline{1}$ & $\mathrm{H}$ & $\mathrm{H}$ & $\mathrm{H}$ & 1,77 & 7,5 & + \\
$\underline{2}$ & $\mathrm{H}$ & $\mathrm{OH}$ & $\mathrm{H}$ & 1,88 & 2,0 & - \\
$\underline{3}$ & $\mathrm{H}$ & $\mathrm{OMe}$ & $\mathrm{H}$ & 1,92 & 6,8 & + \\
$\underline{4}$ & $\mathrm{H}$ & $\mathrm{OH}$ & $\mathrm{OMe}$ & 1,86 & 2,1 & - \\
$\underline{\mathbf{6}}$ & $\mathrm{H}$ & $\mathrm{OMe}$ & $\mathrm{OMe}$ & 1,91 & 4,5 & + \\
$\underline{7}$ & $\mathrm{OMe}$ & $\mathrm{OH}$ & $\mathrm{OMe}$ & 1,83 & 2,1 & - \\
$\underline{8}$ & $\mathrm{OMe}$ & $\mathrm{OMe}$ & $\mathrm{OMe}$ & 1,79 & 4,5 & + \\
\hline
\end{tabular}

* - обратимость электрохимической реакции: «+»- обратимая, «-»- необратимая

Таблица 4. Полярографические характеристики производных ацетофенона [28]

\begin{tabular}{c|c|c|c|c|c|c}
\hline Соединение & $\mathrm{R}_{1}$ & $\mathrm{R}_{2}$ & $\mathrm{R}_{3}$ & $-E_{\mathrm{p}}{ }^{1}, \mathrm{~B}$ & $\mathrm{i}_{\mathrm{p}}{ }^{1}, \mu \mathrm{A}$ & $\mathrm{r}$ \\
\hline$\underline{9}$ & $\mathrm{H}$ & $\mathrm{H}$ & $\mathrm{H}$ & 1,95 & 7,7 & + \\
$\underline{10}$ & $\mathrm{H}$ & $\mathrm{OH}$ & $\mathrm{H}$ & 2,04 & 2,6 & - \\
$\frac{11}{\underline{12}}$ & $\mathrm{H}$ & $\mathrm{OMe}$ & $\mathrm{H}$ & 2,11 & 5,9 & + \\
$\underline{13}$ & $\mathrm{H}$ & $\mathrm{OH}$ & $\mathrm{OMe}$ & 2,02 & 2,4 & - \\
$\underline{14}$ & $\mathrm{H}$ & $\mathrm{OMe}$ & $\mathrm{OMe}$ & 2,07 & 5,3 & + \\
$\underline{15}$ & $\mathrm{OMe}$ & $\mathrm{OH}$ & $\mathrm{OMe}$ & 1,99 & 2,3 & - \\
\hline
\end{tabular}

Таблица 5. Полярографические характеристики производных пропиофенона [28]

\begin{tabular}{c|c|c|c|c|c|cc}
\hline Соединение & $\mathrm{R}_{1}$ & $\mathrm{R}_{2}$ & $\mathrm{R}_{3}$ & $-E_{\mathrm{p}}{ }^{1}, \mathrm{~B}$ & $\mathrm{i}_{\mathrm{p}}{ }^{1}, \mu \mathrm{A}$ & $\mathrm{r}$ \\
\hline$\underline{16}$ & $\mathrm{H}$ & $\mathrm{H}$ & $\mathrm{H}$ & 1,97 & 8,0 & + \\
$\underline{17}$ & $\mathrm{H}$ & $\mathrm{OH}$ & $\mathrm{H}$ & 2,07 & 2,9 & - \\
$\underline{18}$ & $\mathrm{H}$ & $\mathrm{OMe}$ & $\mathrm{H}$ & 2,12 & 6,7 & + \\
$\underline{\underline{20}}$ & $\mathrm{H}$ & $\mathrm{OH}$ & $\mathrm{OMe}$ & 1,86 & 2,1 & - \\
$\underline{\underline{21}}$ & $\mathrm{H}$ & $\mathrm{OMe}$ & $\mathrm{OMe}$ & 2,09 & 5,5 & + \\
$\underline{22}$ & $\mathrm{OMe}$ & $\mathrm{OH}$ & $\mathrm{OMe}$ & 2,01 & 2,3 & - \\
$\underline{23}$ & $\mathrm{OMe}$ & $\mathrm{OMe}$ & $\mathrm{OMe}$ & 1,99 & 4,6 & + \\
$\underline{\underline{24}}$ & $\mathrm{H}$ & $\mathrm{OH}$ & OMe & 1,86 & 2,0 & - \\
$\underline{\underline{25}}$ & $\mathrm{H}$ & Оме & Оме & 1,91 & 3,4 & - \\
\hline
\end{tabular}

Механизм электрохимического восстановления бензальдегида, ацетофенона и пропиофенона в неводных апротонных средах описан в литературе $[11,35]$. На первой стадии происходит перенос одного электрона с образованием соответствующего анион-радикала. Образовавшийся анион-радикал может либо диффундировать в раствор и в нем димеризоваться, либо восстановиться в дианион. Такой же схемой описывается реакции, протекающие в щелочной среде (уравнение 5). Первая стадия, как правило, обратима, вторая - необратима. В присутствии подходящего донора протонов, например фенола, образовавшийся по уравнению (5) анион-радикал протонируется, затем происходит перенос второго электрона (уравнение 6):

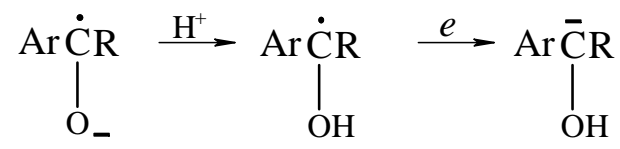


Протонированные частицы восстанавливаются легче (при менее отрицательном потенциале), чем исходное соединение. Поэтому если донор протонов присутствует в достаточной концентрации, стадии, описываемые уравнениями 5, 6, наблюдаются при одном и том же потенциале (одна двухэлектронная полярографическая волна).

В выбранных условиях (ДМСО, ПТБА) бензальдегид, ацетофенон, пропиофенон их производные с блокированным фенольным гидроксилом восстанавливаются в две стадии по известной схеме (уравнения 5, 6). Отметим, что на полярограммах всех исследованных карбонилсодержащих модельных соединений лигнина второй пик расположен при потенциалах, близких к потенциалу восстановления фонового электролита (рис. 1). Поэтому точно определить значения $E_{\mathrm{p}}{ }^{2}$ не представляется возможным, в связи с чем в таблицы 3-5 включены потенциалы только первого пика $\left(E_{\mathrm{p}}{ }^{1}\right)$.

Модельные соединения со свободным фенольным гидроксилом восстанавливаются по иному механизму. Для них нами предложена следующая схема превращений (рис. 2).

Схема составлена по аналогии со схемой восстановления ароматических альдегидов и кетонов в присутствии донора протонов. При потенциале первого пика на полярограммах обсуждаемых соединений протекают реакции, описываемые уравнениями $(5,6)$. Ключевую роль здесь играет реакция автопротонирования (уравнение 8). Молекулы гидроксилсодержащих соединений, протонируя в приэлектродном пространстве образовавшиеся на первой стадии восстановления анион-радикалы, переходят в соответствующие анионы. Являясь отрицательно заряженными частицами, анионы восстанавливаются значительно труднее, чем нейтральные молекулы. Поэтому второй пик на полярограммах гидроксипроизводных отражает, по-видимому, дальнейшее восстановление анионов (уравнение 11). Достаточно отчетливо он проявляется на полярограммах лишь некоторых альдегидов, например сиреневого альдегида (ㅁ) и 5-гидроксиванилина $(\underline{8})$.

Таким образом, при потенциале первого пика в электрохимическую реакцию вступает только часть молекул такого рода соединений, а остальные молекулы выполняют роль доноров протона. Принципиально возможно протонирование как исходного деполяризатора, так и образовавшегося из него анионрадикала. В первом случае при увеличении концентрации вещества в растворе должно наблюдаться смещение пика в область менее отрицательных значений, так как протонированные частицы несут дополнительный положительный заряд. Во втором случае потенциал от концентрации не зависит, поскольку здесь обе стадии восстановления протекают при одном и том же потенциале (см. выше). Как показали исследования, потенциал пика от концентрации не зависит, т.е. эффект автопротонирования реализуется через протонирование анион-радикалов. Автопротонирование анионов (уравнение 10) не влияет на потенциал пика, так как оно происходит после стадии переноса электрона.

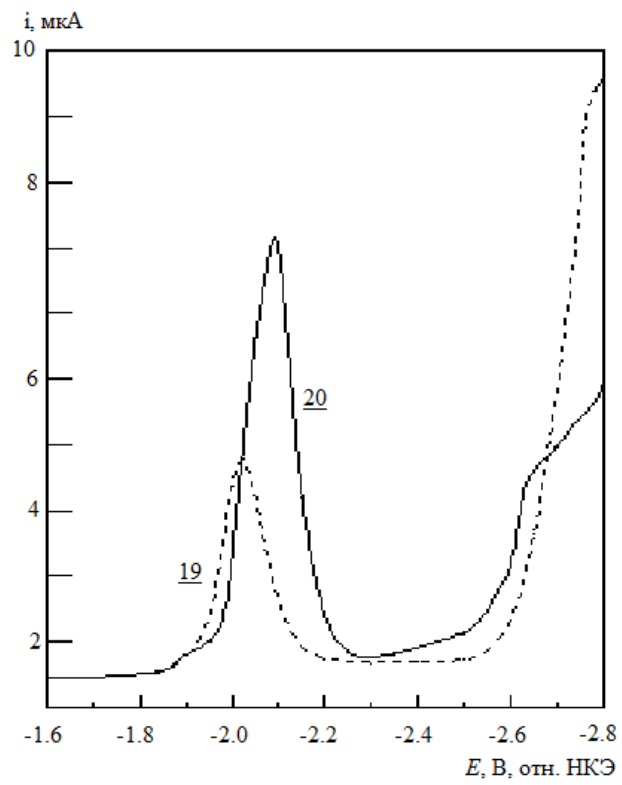

Рис. 1. Полярограммы пропиогваякона (무) и пропиовератрона (20) [28] 


$$
\begin{aligned}
& \underset{\mathrm{O}}{\mathrm{HO}-\mathrm{ArCR}}+e \longrightarrow \underset{!}{\mathrm{HO}-\mathrm{Ar}} \underset{\mathrm{O}_{-}}{\dot{\mathrm{C}} \mathrm{R}}
\end{aligned}
$$

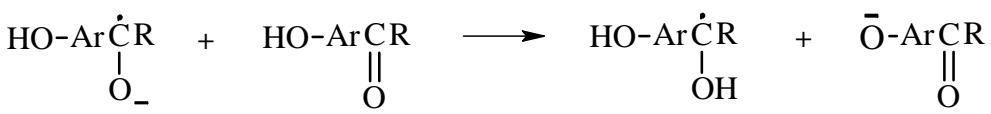

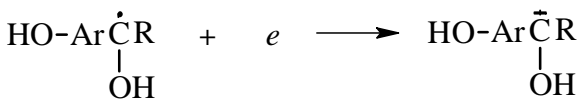

$$
\begin{aligned}
& \underset{\mathrm{O}}{\mathrm{HO}-\mathrm{Ar} \underset{\mathrm{C}}{\mathrm{C} R} \mathrm{R}}+\underset{\mathrm{HO}-\mathrm{ArCR}}{\longrightarrow} \underset{\mathrm{O}}{\mathrm{HO}-\mathrm{ArCHR}}+\underset{\mathrm{O}}{\mathrm{O}}+\underset{\|}{\mathrm{OrCR}}
\end{aligned}
$$

$\mathrm{HO}-\mathrm{Ar}=$ пара-гидроксифенилпропан, гваяцил, сирингил

Рис. 2. Предполагаемая схема восстановления карбонилсодержащих модельных соединений со свободным фенольным гидроксилом [28]

Ароматические кетоны, замещзенные в боковой цепи. Среди производных пропиофенона обращают на себя внимание соединения, замещенные в $\beta$-положении боковой цепи: $\underline{23}, \underline{24}$ и $\underline{25}$, Они восстанавливаются легче других производных при потенциалах меньших, чем $E_{\mathrm{p}}{ }^{1}$ пропиофенона (табл. 5). Если для соединений $\underline{23}$ и 24 можно предположить влияние автопротонирования, то для соединения 25 такое предположение исключено, поскольку оно не содержит гидроксильных групп. Это заставляет искать другое объяснение обнаруженного эффекта.<smiles>COc1cc(C(=O)C(C)O)ccc1O</smiles>

$\underline{23}$<smiles>COc1ccc(C(=O)C(C)O)cc1OC</smiles>

$\underline{24}$<smiles>COc1ccc(C(=O)C(C)OC)cc1OC</smiles>

$\underline{25}$

Известно [36], что карбонильная группа снижает электронную плотность на соседнем атоме углерода, вследствие чего связь С-Х приобретает способность к восстановительному расщеплению.

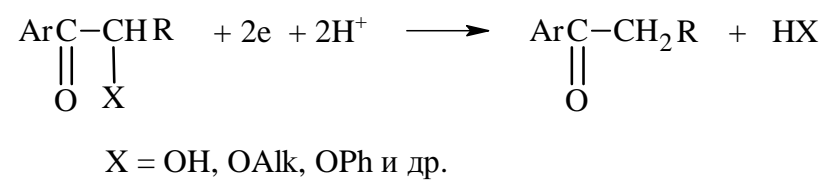

Стадия восстановительного расщепления обычно предшествует восстановлению карбонильной группы, но в некоторых случаях, например при $\mathrm{X}=\mathrm{OH}$, связь С-Х расщепляется приблизительно при том же потенциале, при котором восстанавливается группа $\mathrm{C}=\mathrm{O}$, и оба процесса могут слиться в один [11]. 
Такое слияние двух процессов, по-видимому, и происходит при восстановлении производных пропиофенона $\underline{23}$ и $\underline{24}$, Что же касается кетона $\underline{25}$, то на его полярограмме помимо пика с $E_{\mathrm{p}}=-1,94 \mathrm{~B}$ содержится еще один пик, потенциал которого (-2,08 В) практически совпадает с потенциалом восстановления пропиовератрона (20). Это позволяет отнести пик с $E_{\mathrm{p}}=-2,08$ В к восстановлению соединения (20)$)$, образовавшемуся в результате восстановительного расщепления соединения 25 (уравнение 12).

$\beta$-Карбонильные соединения. Исследованные представители этого класса соединений (26) и $(\underline{27})$ в использованных условиях (ДМСО, ПТБА) оказались полярографически неактивными. Отметим, что в молекулах этих кетонов отсутствует сопряжение между карбонильной группой и ароматическим кольцом, в связи с чем их можно рассматривать как насыщенные карбонильные соединения. Последние значительно менее реакционноспособны, чем ненасыщенные [11, 35, 36].<smiles>[X]c1ccc(CC(C)=O)cc1OC</smiles><smiles>[R]O[R]([R20])=O</smiles>

$\alpha, \beta$-Дикарбонильные соединения. Полярографические характеристики дикетонов $\underline{28}$ и $\underline{29}$ представлены в таблице 6.

Электрохимическое восстановление соединений родственной структуры в неводной апротонной среде протекает в две одноэлектронные стадии, первая из которых обратима [35].

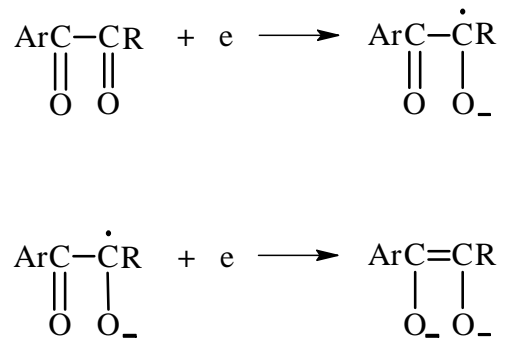

В эту схему хорошо укладываются результаты, полученные при исследовании дикетона 29. По данным ЦВА, первая стадия его восстановления представляет собой одноэлектронный процесс, а вторая необратима.

При сопоставлении полярографических характеристик соединений $\underline{28}$ и 29 (табл. 6) прослеживаются те же закономерности влияния автопротонирования на механизм электрохимической реакции, что и в ряду ароматических альдегидов и кетонов. Иными словами, схема, предложенная для соединений с ОН (уравнения (7-11), по-видимому, применима и для дикетона $\underline{28}$. Тогда первый пик на полярограмме соединения $\underline{28}$ отражает восстановление исходного деполяризатора, второй - восстановление аниона, третий соответствует переносу электронов на протонированную форму дианиона непредельного соединения, образовавшегося при потенциале первого пика (уравнение (14). Тот факт, что $\mathrm{i}_{\mathrm{p}}{ }^{2}>\mathrm{i}_{\mathrm{p}}{ }^{1}$, качественно согласуется с обсуждаемой схемой, поскольку в соответствии с ней при полном восстановлении 1 моля гидроксилсодержащего деполяризатора образуются 2 моля соответствующего аниона. Заметим, что на соотношение высот первого и второго пиков помимо стехиометрии процесса оказывает влияние соотношение скоростей переноса электрона и протонирования.

Таблица 6. Полярографические характеристики $\alpha, \beta$-дикарбонильных соединений [28]

\begin{tabular}{c|c|c|c}
\hline Соединение & $-E_{\mathrm{p}}, \mathrm{B}$ & $\mathrm{i}_{\mathrm{p}}$, мкА & $\mathrm{r}$ \\
\hline$\underline{28}$ & 1,12 & 2,1 & - \\
& 1,68 & 2,7 & - \\
$\underline{29}$ & 2,67 & $*$ & + \\
& 1,16 & 4,3 & - \\
\hline
\end{tabular}


n-Хинонметиды. Среди модельных соединений лигнина хинонметиды представляют особый интерес, поскольку они являются ключевыми интермедиатами реакций лигнификации и делигнификации. Подробно этот класс соединений обсуждается в обзоре [37].

Исследованы модельные хинонметиды 으는. Потенциалы их восстановления представлены в таблице 7. В силу малой устойчивости их не удается выделить в твердом виде, в связи с чем они были синтезированы в хлористом метилене [38, 39]. Определенный объем полученного раствора (не выше $10 \%$ по объему) смешивался с ДМСО, содержащим фоновый электролит (ПТБА). В этих условиях модельные хинонметиды были устойчивы в течение по крайней мере 1 ч. В отдельном исследовании с использованием стабильных хинонметидов с близкими значениями потенциалов установлено, что добавление такого количества $\mathrm{CH}_{2} \mathrm{Cl}_{2}$ в анализируемый раствор не оказывает заметного влияния на $E_{1 / 2}$.<smiles>[R]CC=C1C=CC(=O)C(OC)=C1</smiles>

$\underline{30} \mathrm{R}=\mathrm{H}$

$\underline{31} \mathrm{R}=\mathrm{Me}$<smiles>C=C/C=C1\C=CC(=O)C(OC)=C1</smiles>

$\underline{32}$<smiles>[R2]C1=CC(=CC([R])Oc2ccc([R])cc2OC)C=CC1=O</smiles>

$\underline{33} \mathrm{R}_{1}=\mathrm{R}_{2}=\mathrm{R}_{3}=\mathrm{H}$

$\underline{34} \mathrm{R}_{1}=\mathrm{Me}, \mathrm{R}_{2}=\mathrm{OMe}, \mathrm{R}_{3}=\mathrm{H}$

$\underline{35} \mathrm{R}_{1}=\mathrm{Me}, \mathrm{R}_{2}=\mathrm{OMe}, \mathrm{R}_{3}=\mathrm{CH}=\mathrm{CHMe}$<smiles>COC1=CC(=CCc2ccccc2)C=CC1=O</smiles>

36

Таблица 7. Потенциалы восстановления модельных р-хинонметидов [30]

\begin{tabular}{c|c|c|c|c|c|c|c}
\hline Соединение & $\underline{30}$ & $\underline{31}$ & $\underline{32}$ & $\underline{33}$ & $\underline{34}$ & $\underline{35}$ & $\underline{36}$ \\
\hline$-E_{1 / 2}, \mathrm{~B}$ & 1,12 & 1,14 & 0,90 & 0,81 & 0,96 & 0,96 & 1,10 \\
\hline
\end{tabular}

На полярограммах этих соединений содержится только одна волна, и, судя по данным ЦВА, все они восстанавливаются необратимо. Хинонметид $\underline{34}$ и два других хинонметида близкого строения ранее также исследовались методом ЦВА в сходных условиях (ДМСО, ПТБА, 1-5\% $\mathrm{CHCl}_{3}$ ), и получены аналогичные результаты [40]. В то же время стабильные хинонметиды (стерически затрудненные) в неводной среде восстанавливаются в две одноэлектронные стадии, первая из которых обратима, а вторая осложнена побочными процессами, главным образом, димеризацией и дисмутацией анион-радикалов [41, 42].

$$
\mathrm{QM}+\mathrm{e} \longrightarrow \mathrm{QM}^{-}
$$

$$
\mathrm{QM}^{-}+\mathrm{e} \longrightarrow \mathrm{QM}^{2-}
$$

Необратимость процесса восстановления модельных хинонметидов лигнина затрудняет определение числа переносимых при этом электронов методом ЦВА. Однако имеются некоторые данные, свидетельствующие о том, что электрохимическая реакция с их участием протекает по уравнению (15), а за ней следует быстрая химическая реакция анион-радикалов с образованием полярографически неактивных продуктов [40].

Учитывая важную роль хинонметидов в реакциях лигнина, помимо соединений $\underline{30}-\underline{36}$, в обсуждение реакционной способности при электрохимическом восстановлении включены также их стабильные аналоги. С тем чтобы не нарушать сквозную нумерацию исследованных нами соединений, они обозначены римскими цифрами. Для приведения потенциалов всех изученных хинонметидов к единой шкале литературные данные скорректированы на величину $\Delta E_{1 / 2}$, полученную сравнением $E_{1 / 2}$, одних и тех же соединений (IIa-IIf, IIIa) в условиях, использованных в работе [30] и в работах [41-43]. Последние также проводились в апротонном растворителе (ДМФ) на фоне ПТБА, но с иным электродом сравнения. Результаты приведены в таблицах 8-10, в которые включены потенциалы первой волны восстановления. 
<smiles>[R]C([R])=C1C=C(C(C)(C)C)C(=O)C(C(C)(C)C)=C1</smiles>

II<smiles>O=C1C=CC(=C(c2ccccc2)c2ccccc2)c2ccccc21</smiles>

$\mathrm{Va}$<smiles>[R]C1=CC(=C(c2ccccc2)c2ccccc2)C=C([R])C1=O</smiles>

III<smiles>O=C1C=CC(=C2SCCS2)c2ccccc21</smiles>

$\mathrm{Vb}$<smiles>O=C1C=CC(=C2SCCS2)C=C1</smiles>

IV<smiles>[R]C([R])=C1c2ccccc2C(=O)c2ccccc21</smiles>

VI

Для соединений IV, $\mathrm{Va}, \mathrm{Vb}$ потенциал полуволны составил, соответственно, $-1,12,-0,97,-1,25$ B [41, 42].

Сопоставление $-E_{1 / 2}^{1}$ в таблицах 8-10 позволило охарактеризовать изменения реакционной способности при изменении структуры во всей серии исследованных хинонметидов и определить место модельных хинонметидов лигнина в этой серии [30]. Как показали квантово-химические расчеты, несмотря на необратимость электрохимического восстановления, последние (за исключением соединения 32) вместе со стабильными аналогами образуют единый ряд в координатах $-E_{1 / 2}^{1}-$ энергия низшей вакантной молекулярной орбитали с коэффициентом корреляции 0,97 . Это означает, что необратимость обусловлена не замедленной стадией переноса электрона, а последующими достаточно быстрыми химическими превращениями. Кроме того, у всех соединений обсуждаемой серии реакционный центр локализован на атоме $\mathrm{C}^{\alpha}$.

Таблица 8. Полярографические потенциалы хинонметидов серии II [41-43]

\begin{tabular}{|c|c|c|c|}
\hline Соединение & $\mathrm{R}_{1}$ & $\mathrm{R}_{2}$ & $-E_{1 / 2}^{1}, \mathrm{~B}$, отн. НКЭ \\
\hline IIa & $\mathrm{H}$ & $\mathrm{i}-\mathrm{C}_{3} \mathrm{H}_{7}$ & 1,39 \\
\hline $\mathrm{IIb}$ & $\mathrm{H}$ & $\mathrm{CN}$ & 0,67 \\
\hline IIc & $\mathrm{H}$ & $\mathrm{CO}_{2} \mathrm{CH}_{3}$ & 0,70 \\
\hline IId & $\mathrm{CH}_{3}$ & $\mathrm{CH}_{3}$ & 1,39 \\
\hline IIe & $\mathrm{CN}$ & $\mathrm{CN}$ & 0,13 \\
\hline IIf & $\mathrm{C}_{6} \mathrm{H}_{5}$ & $\mathrm{C}_{6} \mathrm{H}_{5}$ & 1,13 \\
\hline IIg & $\mathrm{NC}_{5} \mathrm{H}_{10}$ & $\mathrm{NC}_{5} \mathrm{H}_{10}$ & 2,15 \\
\hline IIh & $\mathrm{H}$ & $\mathrm{C}_{6} \mathrm{H}_{5}$ & 1,09 \\
\hline IIi & $\mathrm{n}-\mathrm{C}_{4} \mathrm{H}_{9}$ & $\mathrm{C}_{6} \mathrm{H}_{5}$ & 1,3 \\
\hline $\mathrm{IIj}$ & $\mathrm{CH}_{3}$ & $\mathrm{C}_{6} \mathrm{H}_{5}$ & 1,25 \\
\hline IIk & $\mathrm{CN}$ & $\mathrm{C}_{6} \mathrm{H}_{5}$ & 0,66 \\
\hline III & $\mathrm{NC}_{5} \mathrm{H}_{10}$ & $\mathrm{C}_{6} \mathrm{H}_{5}$ & 1,54 \\
\hline $\mathrm{IIm}$ & $\mathrm{SC}_{6} \mathrm{H}_{5}$ & $\mathrm{C}_{6} \mathrm{H}_{5}$ & 1,06 \\
\hline IIn & $\mathrm{SO}_{2} \mathrm{C}_{6} \mathrm{H}_{5}$ & $\mathrm{C}_{6} \mathrm{H}_{5}$ & 0,70 \\
\hline IIo & $\mathrm{COC}_{6} \mathrm{H}_{5}$ & $\mathrm{C}_{6} \mathrm{H}_{5}$ & 0,82 \\
\hline IIp & $\mathrm{H}$ & $\mathrm{NC}_{5} \mathrm{H}_{10}$ & 1,78 \\
\hline IIr & $\mathrm{NC}_{5} \mathrm{H}_{10}$ & $\mathrm{CN}$ & 0,97 \\
\hline IIs & $\mathrm{NC}_{5} \mathrm{H}_{10}$ & $\mathrm{SCH}_{3}$ & 1,52 \\
\hline IIt & \multicolumn{2}{|c|}{$-\mathrm{SCH}_{2} \mathrm{CH}_{2} \mathrm{~S}-$} & 1,35 \\
\hline $\mathrm{IIu}$ & $\mathrm{CH}_{3}$ & $\mathrm{CN}$ & 0,77 \\
\hline IIv & $\mathrm{i}-\mathrm{C}_{3} \mathrm{H}_{7}$ & $\mathrm{CN}$ & 0,80 \\
\hline IIw & $\mathrm{H}$ & $\mathrm{H}$ & 1,2 \\
\hline IIx & $\mathrm{H}$ & $\mathrm{CH}_{3}$ & 1,33 \\
\hline IIy & $\mathrm{CN}$ & $\mathrm{C}_{2} \mathrm{H}_{5}$ & 0,79 \\
\hline $\mathrm{IIz}$ & $\mathrm{H}$ & $\mathrm{OCH}_{3}$ & 1,52 \\
\hline IIaa & $\mathrm{H}$ & $\mathrm{Cl}$ & 1,03 \\
\hline
\end{tabular}


Таблица 9. Полярографические потенциалы хинонметидов серии III [41-43]

\begin{tabular}{|c|c|c|c|}
\hline Соединение & $\mathrm{R}_{1}$ & $\mathrm{R}_{2}$ & $-E_{1 / 2}^{1}, \mathrm{~B}$, отн. НКЭ \\
\hline IIIa & $\mathrm{CH}_{3}$ & $\mathrm{CH}_{3}$ & 1,04 \\
\hline IIIb & $\mathrm{H}$ & $\mathrm{H}$ & 0,91 \\
\hline IIIc & $\mathrm{C}_{2} \mathrm{H}_{5}$ & $\mathrm{C}_{2} \mathrm{H}_{5}$ & 1,06 \\
\hline IIId & $\mathrm{i}-\mathrm{C}_{3} \mathrm{H}_{7}$ & $\mathrm{i}-\mathrm{C}_{3} \mathrm{H}_{7}$ & 1,06 \\
\hline IIIe & $\mathrm{OCH}_{3}$ & $\mathrm{OCH}_{3}$ & 0,99 \\
\hline IIIf & $\mathrm{Br}$ & $\mathrm{Br}$ & 0,60 \\
\hline IIIg & $\mathrm{CH}_{3}$ & $\mathrm{t}-\mathrm{C}_{4} \mathrm{H}_{9}$ & 1,08 \\
\hline IIIh & $\mathrm{H}$ & $\mathrm{CH}_{3}$ & 0,98 \\
\hline IIIi & $\mathrm{H}$ & $\mathrm{C}_{2} \mathrm{H}_{5}$ & 1,01 \\
\hline IIIj & $\mathrm{H}$ & $\mathrm{i}-\mathrm{C}_{3} \mathrm{H}_{7}$ & 0,99 \\
\hline IIIk & $\mathrm{H}$ & $\mathrm{t}-\mathrm{C}_{4} \mathrm{H}_{9}$ & 1,00 \\
\hline IIIl & $\mathrm{H}$ & $\mathrm{OCH}_{3}$ & 0,95 \\
\hline IIIm & $\mathrm{H}$ & $\mathrm{Br}$ & 0,77 \\
\hline
\end{tabular}

Таблица 10. Полярографические потенциалы хинонметидов серии VI [30, 41, 42]

\begin{tabular}{c|c|c|c}
\hline Соединение & $\mathrm{R}_{1}$ & $\mathrm{R}_{2}$ & $-E_{1 / 2}^{1}, \mathrm{~B}$, отн. НКЭ \\
\hline VIa & $\mathrm{H}$ & $\mathrm{H}$ & 1,20 \\
VIb & $\mathrm{H}$ & $\mathrm{C}_{6} \mathrm{H}_{5}$ & 1,20 \\
VIc & $\mathrm{H}$ & $\mathrm{p}-\mathrm{HOC}_{6} \mathrm{H}_{4}$ & 1,27 \\
VId & $\mathrm{m}-\mathrm{HOC}_{6} \mathrm{H}_{4}$ & 1,23 \\
VIe & $\mathrm{H}$ & $\mathrm{p}-\mathrm{H}_{3} \mathrm{COC}_{6} \mathrm{H}_{4}$ & 1,24 \\
VIf & $\mathrm{H}$ & $\mathrm{p}-\mathrm{HO}\left(\mathrm{m}^{-} \mathrm{H}_{3} \mathrm{CO}\right) \mathrm{C}_{6} \mathrm{H}_{3}$ & 1,25 \\
VIg & $\mathrm{H}-\left(\mathrm{CH}_{3}\right)_{2} \mathrm{NC}_{6} \mathrm{H}_{4}$ & 1,28 \\
VIh & $\mathrm{C}_{6} \mathrm{H}_{5}$ & $\mathrm{C}_{6} \mathrm{H}_{5}$ & 1,06 \\
VIi & \multicolumn{2}{|c|}{$-\mathrm{SCH}_{2} \mathrm{CH}_{2} \mathrm{~S}-\quad-1,45$} \\
\hline
\end{tabular}

Соединения, содержащие сопряженную двойную связь. Общее содержание сопряженных двойных связей в ЛМР ели составляет около 7 на 100 ФПЕ, причем они распределены приблизительно поровну между структурами типа кониферилового альдегида и кониферилового спирта. В сосновом сульфатном лигнине их содержание оценивается в 7-8/100 ФПЕ, и они входят главным образом в стильбеновые структуры [2].

Исследованы следующие соединения, моделирующие $\alpha, \beta$-ненасыщенные структуры лигнина: изоэвгенол, конифериловый спирт и производные коричного альдегида, в том числе конифериловый альдегид. С целью сравнительного изучения влияния $\gamma$-заместителя на реакционную способность двойной связи в дополнение к ним исследованы также производные коричной кислоты. Результаты изучения этих производных представляют и самостоятельный интерес, так как, во-первых, они являются предшественниками лигнина в ходе его биосинтеза, и, во-вторых, некоторые из них, например феруловая кислота, химически связана с лигнином травянистых растений [2].

Изоэвгенол и конифериловый спирт. Эти соединения (그 и $\underline{38})$ восстанавливаются при потенциалах, близких потенциалу разряда фонового электролита (около $-2,80$ В), в связи с чем для них не удается определить значения $E_{\mathrm{p}}$ и $\mathrm{i}_{\mathrm{p}}$. Таким образом, двойная связь, сопряженная с ароматическим кольцом, в том числе связь, активированная $\gamma$-метилольной группой, относится к числу трудновосстанавливаемых связей лигнина.<smiles>C/C=C/c1ccc(O)c(OC)c1</smiles>

$\underline{37}$<smiles>COc1cc(/C=C/CO)ccc1O</smiles>

$\underline{38}$

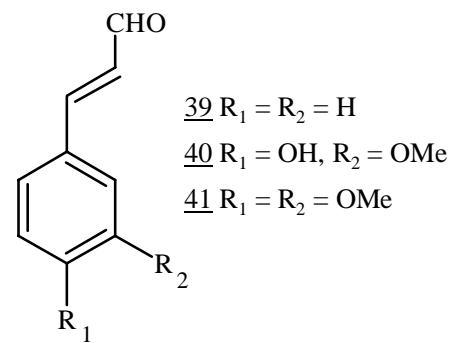
$\underline{40} \mathrm{R}_{1}=\mathrm{OH}, \mathrm{R}_{2}=\mathrm{OMe}$ $\underline{41} \mathrm{R}_{1}=\mathrm{R}_{2}=\mathrm{OMe}$ 


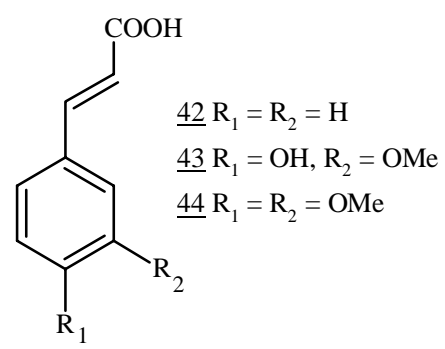<smiles>CC(=O)C=Cc1ccccc1</smiles>

Производнье коричного альдегида. Результаты исследования коричного альдегида и его производных (соединения $\underline{39}, \underline{41}$ ) представлены в таблице 11. Реакция электрохимического восстановления ненасыщенных карбонилсодержащих соединений, в том числе и коричного альдегида (푸), в неводных средах (ДМСО, ДМФ) состоит в последовательном присоединении двух электронов и двух протонов с образованием соответствующего насыщенного соединения.

Механизм реакции достаточно сложен. Она начинается с переноса одного электрона на карбонильную группу, включает стадии переноса электрона и перегруппировки деполяризатора и заканчивается регенерацией карбонильной группы [11, 35, 44].

Образующиеся на первой стадии восстановления анион-радикалы неустойчивы и быстро вступают в реакцию димеризации [44]. Вероятно, поэтому в выбранных нами условиях на циклических вольтамперограммах коричного альдегида $\mathrm{i}_{\mathrm{a}}<\mathrm{i}_{\mathrm{c}}$. Как показывают данные ЦВА и ДИП, восстановление 3,4-диметоксикоричного альдегида (1ㅜ) также протекает по известной схеме. Что же касается кониферилового альдегида (0ㅡ), то уже простое сопоставление полярограмм показало, что и в этом случае определяющее влияние на процесс оказывает реакция автопротонирования. Анализ значений $E_{\mathrm{p}}$ и $\mathrm{i}_{\mathrm{p}}$ в исследованном ряду производных коричного альдегида приводит нас к тем же выводам, которые были сделаны относительно роли фенольных гидроксилов на процесс электрохимического восстановления ароматических альдегидов и кетонов (см. выше).

Таблица 11. Полярографические характеристики производных коричного альдегида [28]

\begin{tabular}{c|c|c|c}
\hline Соединение & $-E_{\mathrm{p}}, \mathrm{B}$ & $\mathrm{i}_{\mathrm{p}}$, мкА & $\mathrm{r}$ \\
\hline$\underline{39}$ & 1,45 & 6,7 & - \\
\multirow{4}{40}{} & 2,08 & 2,1 & - \\
\multirow{4}{4}{} & 1,48 & 1,8 & - \\
& 2,02 & 2,7 & - \\
\hline
\end{tabular}

Производные коричной кислоты. В таблице 12 представлены результаты исследования коричной ки-

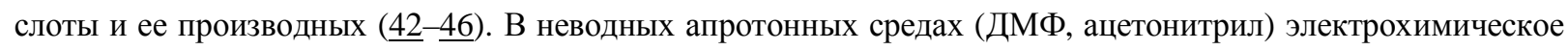
восстановление сложных эфиров коричной кислоты, например ее этилового эфира, протекает в две одноэлектронные стадии и приводит к насыщению двойной связи, причем реакция осложнена димеризацией продуктов, образующихся при потенциале первой волны [45].

В выбранных условиях (ДМСО, ПТБА) метиловый эфир коричной кислоты (45) тоже восстанавливается в две стадии, причем высота первого пика выше высоты второго (табл. 12). В случае же коричной кислоты (42) соотношение высот пиков изменяется на противоположное, т.е. аналогично тому, как это происходило в ряду ароматических альдегидов и кетонов при введении в молекулу деполяризатора фенольного гидроксила (см. выше). Иными словами, реакция автопротонирования протекает и при восстановлении карбоксилсодержащих соединений.

Таблица 12. Полярографические характеристики производных коричной кислоты [28]

\begin{tabular}{c|c|c|c}
\hline Соединение & $-E_{\mathrm{p}}, \mathrm{B}$ & $\mathrm{i}_{\mathrm{p}}$, мкА & $\mathrm{r}$ \\
\hline$\underline{42}$ & 1,70 & 2,6 & - \\
$\underline{43}$ & 2,44 & 4,5 & - \\
\multirow{4}{4}{} & 1,83 & 2,2 & - \\
$4 \underline{45}$ & 2,60 & 1,0 & - \\
& 1,80 & 2,4 & - \\
\hline
\end{tabular}


При этом сама карбоксильная группа не восстанавливается и служит лишь источником протонов. Об этом свидетельствуют результаты исследования дигидрокоричной кислоты (흐). На полярограммах этого соединения в данных условиях (ДМСО, ПТБА) не содержится пиков восстановления, т.е. оно не обладает полярографической активностью. Подобно коричной кислоте восстанавливается модельное соединение 44 с блокированным фенольным гидроксилом, для которого $\mathrm{i}_{\mathrm{p}}{ }^{1}<\mathrm{i}_{\mathrm{p}}{ }^{2}$, Что же касается феруловой кислоты (43), содержащей одновременно и карбоксильную группу, и фенольный гидроксил, то механизм ее восстановления, по-видимому, более сложен и требует дополнительного изучения.

Ароматические кислоты. Карбоксильная группа не является типичной функциональной группой природного лигнина. В то же время некоторые исследователи установили, что в ЛМР содержится приблизительно 5 СООН на 100 ФПЕ [46, 47]. В технических лигнинах содержание этих групп значительно выше: например, в сосновом сульфатном лигнине оно составляет $16 \mathrm{COOH} \mathrm{на} 100$ ФПЕ [47]. Еще более высоким содержанием карбоксильных групп характеризуются окисленные лигнины, в частности лигнины, выделенные в ходе кислородно-щелочной отбелки сульфатной целлюлозы [48].

Как уже отмечалось при рассмотрении производных коричной кислоты (см. выше), алифатическая карбоксильная группа является полярографически неактивной. Поэтому исследовались ароматические кислоты, являющиеся производными бензойной кислоты $\underline{47-\underline{53}}$ и ее метилового эфира $\underline{54} \underline{57}$. Результаты представлены в таблице 13.

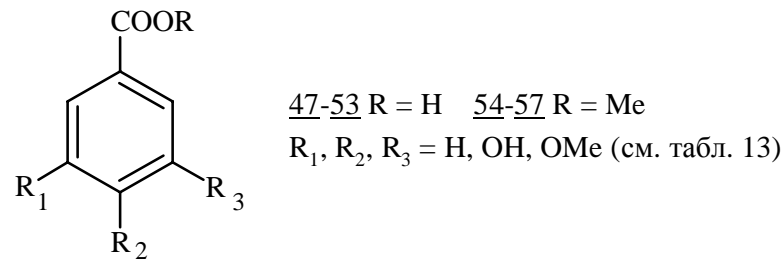

При электрохимическом восстановлении бензойной кислоты в неводной апротонной среде доминирующую роль играет реакция автопротонирования. Например, в ДМФ восстанавливается лишь около $20 \%$ бензойной кислоты (до бензальдегида и бензилового спирта), а остальные $80 \%$ играют роль донора протонов [11]. В выбранных условиях (ДМСО, ПТБА) восстановление бензойной кислоты и ее производных протекает, вероятно, сходным образом.

Об этом, в частности, свидетельствует сопоставление высот пиков на полярограммах исследованных соединений в таблице 13. Если выбрать за единицу высоту пика метилового эфира бензойной кислоты (54), процесс электрохимического восстановления которого не осложнен реакцией автопротонирования и, по данным ЦВА, протекает обратимо, то получается, что в ДМСО восстанавливается $45 \%$ бензойной кислоты

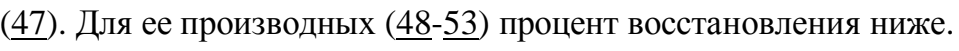

Влияние заместителей в бензольном кольце на потенциал восстановления в ряду производных бензойной кислоты соответствует электронным эффектам этих заместителей. Как показывает попарное сопоставление $E_{\mathrm{p}}$ соединений $\underline{48}$ и $\underline{49}, \underline{50}$ и $\underline{51}, \underline{52}$ и $\underline{53}$, пара-гидроксипроизводные восстанавливаются труднее, чем соответствующие napa-метоксипроизводные. Это позволяет сделать заключение о том, что фенольный гидроксил в реакции автопротонирования не участвует. Введение в мета-положение метоксильной группы вызывает смещение $E_{\mathrm{p}}$ в область менее отрицательных значений (см. $E_{\mathrm{p}}$ для соединений $\underline{48}, \underline{50}, \underline{52}$ и $\underline{49}, \underline{51}$, $\underline{53}$ соответственно).

Среди производных метилового эфира бензойной кислоты лишь соединение $\underline{55}$, содержащее фенольный гидроксил, восстанавливается необратимо и имеет приблизительно вдвое меньший по высоте пик на полярограмме по сравнению с незамещенным аналогом 54. Очевидно, в этом случае процесс электрохимического восстановления включает реакцию автопротонирования образующихся анион-радикалов.

В заключение исследования мономерных модельных соединений лигнина необходимо отметить следующее. Сопоставление значений $E_{\mathrm{p}}{ }^{1}$ в рядах ароматических альдегидов, кетонов и кислот (табл. 3-6, 11-13) показывает, что реакционная способность этих соединений зависит от того, к какому типу элементарных звеньев лигнина они принадлежат, и уменьшается в следующем ряду: сирингильный, гваяцильный, р-гидроксифенилпропановый. 
Таблица 13. Полярографические характеристики производных бензойной кислоты [28]

\begin{tabular}{c|c|c|c|c|c|c}
\hline Соединение & $\mathrm{R}_{1}$ & $\mathrm{R}_{2}$ & $\mathrm{R}_{3}$ & $-E_{\mathrm{p}}, \mathrm{B}$ & $\mathrm{i}_{\mathrm{p}}$, мкA & $\mathrm{r}$ \\
\hline$\underline{47}$ & $\mathrm{H}$ & $\mathrm{H}$ & $\mathrm{H}$ & 2,11 & 2,7 & - \\
$\underline{\mathbf{4 8}}$ & $\mathrm{H}$ & $\mathrm{OH}$ & $\mathrm{H}$ & 2,38 & 2,2 & - \\
$\underline{\mathbf{5 0}}$ & $\mathrm{H}$ & $\mathrm{OMe}$ & $\mathrm{H}$ & 2,29 & 2,0 & - \\
$\underline{\mathbf{5 1}}$ & $\mathrm{H}$ & $\mathrm{OH}$ & $\mathrm{OMe}$ & 2,35 & 2,0 & - \\
$\underline{\mathbf{5 2}}$ & $\mathrm{H}$ & $\mathrm{OMe}$ & $\mathrm{OMe}$ & 2,25 & 2,0 & - \\
$\underline{\underline{53}}$ & $\mathrm{OMe}$ & $\mathrm{OH}$ & $\mathrm{OMe}$ & 2,31 & 1,2 & - \\
$\underline{\mathbf{5 4}}$ & $\mathrm{OMe}$ & $\mathrm{OMe}$ & $\mathrm{OMe}$ & 2,19 & 2,2 & - \\
$\underline{\underline{55}}$ & $\mathrm{H}$ & $\mathrm{H}$ & $\mathrm{H}$ & 2,16 & 6,0 & + \\
$\underline{\underline{57}}$ & $\mathrm{H}$ & $\mathrm{OH}$ & $\mathrm{H}$ & 2,36 & 3,1 & - \\
\hline
\end{tabular}

Наличие в молекуле соединения кислых групп (фенольных или карбоксильных) осложняет процесс электрохимического восстановления за счет реакции автопротонирования. Поэтому с аналитической точки зрения модельные соединения лигнина, содержащие такие группы, предпочтительнее исследовать в виде соответствующих эфиров. Соединения, содержащие несопряженную карбонильную группу $(\underline{26}, \underline{27})$ или несопряженную карбоксильную группу (능), полярографически неактивны.

Исследование димерных модельных соединений.

Известно два типа связей между ФПЕ лигнина: простые эфирные и углерод-углеродные [2]. В соответствии с современными экспериментальными данными, преобладают первые из них, к которым относятся связи $\beta-О-4$ (49-51/100 ФПЕ), $\alpha-O-4$ (6-13/100 ФПЕ), $\alpha-O-\gamma$ (6/100 ФПЕ). Среди углерод-углеродных доминируют связи 5-5, 5-6 (19-22/100 ФПЕ). Имеются также связи $\beta-5$ в фенилкумарановых структурах (11/100 ФПЕ) и $\beta-\beta$ в пинорезинольных структурах (2-10/100 ФПЕ). В технических лигнинах возможно наличие сопряженных двойных связей в структурах типа стильбена и энолового эфира.

Соединения, содержащче простые эфирные связи.

Связь $\beta$-O-4. Расщепление связей $\beta-O-4$, доминирующих в лигнине, представляет особый интерес с точки зрения его деструкции. В работе [25] при интерпретации полярограмм модельных димеров на основании исследований Лунда [49] предполагалось, что электрохимическое расщепление этих связей происходит только при наличии в $\alpha$-положении боковой цепи карбонильной группы, причем расщепление связи предшествует восстановлению активирующей группы. Реакция протекает по уравнению

$$
\operatorname{Ar}(\mathrm{C}=\mathrm{O}) \mathrm{CH}\left(\mathrm{OAr}^{\prime}\right) \mathrm{R}+2 \mathrm{e}^{-}+2 \mathrm{H}^{+} \longrightarrow \mathrm{Ar}(\mathrm{C}=\mathrm{O}) \mathrm{CH}_{2} \mathrm{R}+\mathrm{Ar}^{\prime} \mathrm{OH}
$$

Впоследствии такой механизм реакции был подтвержден результатами анализа продуктов электролиза димеров сходного строения в неводной среде [50], а также результатами полярографических исследований в щелочной водно-органической среде [51].

В ДМСО на фоне ПТБА димер $\underline{58}$ полярографически неактивен [29]. Результаты изучения димеров 59-62 представлены в таблице 14, на рисунке 3. На полярограммах димеров, не содержащих гидроксильных групп (59, $\underline{60})$, имеется два пика приблизительно одинаковых по высоте, причем потенциал второго пика практически совпадает с потенциалами восстановления 3,4-диметоксиацетофенона $(\underline{13})$ и 3,4диметоксипропиофенона (20) соответственно (табл. 4, 5), т.е. кетонов, образующихся при расщеплении связи $\beta-\mathrm{O}-4$ в указанных димерах. Следовательно, реакции электрохимического расщепления этой связи соответствует пик с $E_{\mathrm{p}}=-1,78 \mathrm{~B}$.

При наличии в $\gamma$-положении боковой цепи гидроксильной группы (соединение (1ㅡ) расщепление связи и восстановление соответствующего кетона происходит при менее отрицательных потенциалах (табл. 14.). Иными словами, $\gamma$-метилольная группа оказывает активирующее влияние на рассматриваемые реакции. 
<smiles>COc1cc(C(O)C(C)Oc2ccccc2OC)ccc1O</smiles>

$\underline{58}$<smiles>[R]c1ccc(C(=O)C([R])Oc2ccccc2OC)cc1OC</smiles>

$\underline{59} \mathrm{R}=\mathrm{OMe}, \mathrm{R}_{1}=\mathrm{H}$

$\underline{60} \mathrm{R}=\mathrm{OMe}, \mathrm{R}_{1}=\mathrm{Me}$

$\underline{61} \mathrm{R}=\mathrm{OMe}, \mathrm{R}_{1}=\mathrm{CH}_{2} \mathrm{OH}$

$\underline{62} \mathrm{R}=\mathrm{OH}, \mathrm{R}_{1}=\mathrm{Me}$

Таблица 14. Полярографические характеристики соединений, содержащих связь $\beta-\mathrm{O}-4$ [29]

\begin{tabular}{c|c|c|c|c|c}
\hline Соединение & $\mathrm{R}$ & $\mathrm{R}_{1}$ & $-E_{\mathrm{p}}, \mathrm{B}$ & $\mathrm{i}_{\mathrm{p}}$, мкА & $\mathrm{r}$ \\
\hline$\underline{59}$ & $\mathrm{OMe}$ & $\mathrm{H}$ & 1,78 & 4,1 & - \\
$\underline{60}$ & & & 2,09 & 4,5 & - \\
& $\mathrm{OMe}$ & $\mathrm{Me}$ & 1,78 & 5,5 & - \\
$\underline{61}$ & $\mathrm{OMe}$ & $\mathrm{CH}_{2} \mathrm{OH}$ & 2,08 & 5,8 & - \\
& & & 2,74 & 4,5 & - \\
$\underline{62}$ & $\mathrm{OH}$ & $\mathrm{Me}$ & 1,89 & 1,6 & - \\
\hline
\end{tabular}

Полярограмма димера со свободным фенольным гидроксилом (62) существенно отличается от полярограмм соединений $\underline{59-61}$ (рис. 3). Она тоже содержит два пика. Первый из них имеет $E_{\mathrm{p}}=-1,81 \mathrm{~B}$, тогда как второй (приблизительно удвоенной высоты) расположен при весьма отрицательном потенциале с $E_{\mathrm{p}}=-2,61 \mathrm{~B}$.

По-видимому, и в этом случае на реакцию электрохимического восстановления существенное влияние оказывает автопротонирование деполяризатора, схема которого описана при обсуждении результатов исследования ароматических альдегидов и кетонов (рис. 2). С учетом влияния автопротонирования можно предположить, что при $E_{\mathrm{p}}=-1,81 \mathrm{~B}$ соединение (2) восстанавливается в нейтральной форме, а при $E_{\mathrm{p}}=-$ $2,61 \mathrm{~B}$ - в форме аниона, причем оба эти пика отвечают электрохимическому расщеплению связи $\beta-\mathrm{O}-4$. Пик восстановления кетона, образующегося при $E_{\mathrm{p}}=-1,81 \mathrm{~B}$, вероятно, перекрывается пиком, отражающим расщепление связи. Так, ширина первого пика на полувысоте для соединения $\underline{60}$ составляет $120 \mathrm{MB}$, в то время как для соединения $\underline{62}$ она составляет $160 \mathrm{MB}$.

Связь $\alpha-O-4$. Исследование соединений, содержащих этот тип связи, а именно димера $\underline{63}$ (фенилкумарановая структура) и тримера $\underline{64}$ ( $\alpha, \beta$-дигваяциловый эфир гваяцилпропана), показало, что они полярографически неактивны.

Связь $\alpha-O-\gamma$. Соединение $\underline{65}$ (пинорезинол), содержащее этот тип связи, полярографически неактивно.

Рис. 3. Полярограммы $\beta$-гваяцилового эфира $\alpha$-вератрилпропанона (무) и $\beta$-гваяцилового эфира $\alpha$-гваяцилпропанона (므) [29]

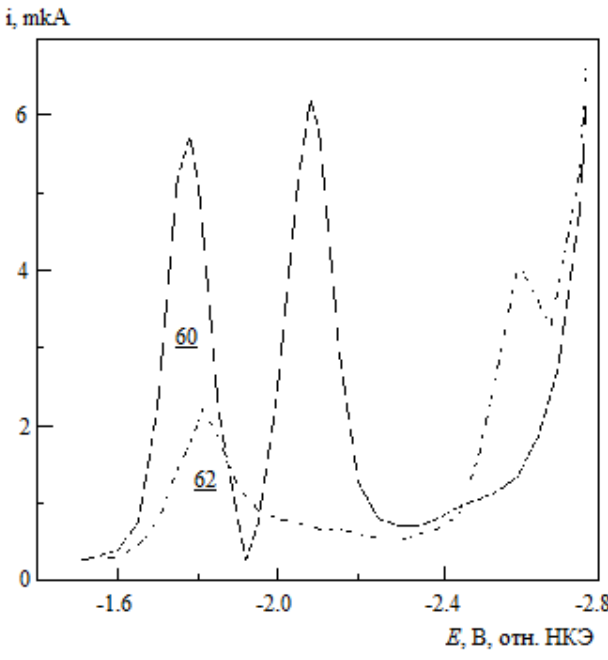




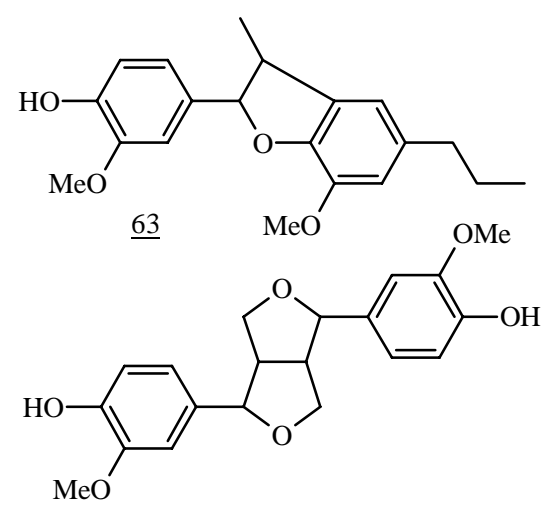<smiles>COc1cc(C(Oc2ccccc2OC)C(C)Oc2ccccc2OC)ccc1O</smiles>

$\underline{64}$

$\underline{65}$

Соединения, содержащчие углерод-углеродные связи

Связь 5-5 (дифенильная структура). В соответствии с данными литературы восстановление дифенила (соединение $\underline{66}$ ) в 75\%-ном водном диоксане на фоне йодистого тетрабутиламмония происходит при высоком отрицательном значении потенциала $\left(E_{1 / 2}=-2,7 \mathrm{~B}\right.$, отн. НКЭ) и приводит к насыщению одной из двойных связей [35]. В выбранных условиях (ДМСО, ПТБА) на полярограмме дифенила имеется пик с $E_{\mathrm{p}}=$ $-2,5$ В, который, по данным ЦВ, соответствует обратимому переносу одного электрона.

Результаты исследования модельных соединений лигнина, являющихся производными дифенила, представлены в таблице 15. Можно заметить, что димеры, не содержащие карбонильных групп (ㅎ7, $\underline{68})$, восстанавливаются при потенциалах, близких $E_{\mathrm{p}}$ дифенила: $-2,52$ В и $-2,55$ В соответственно. При введении в молекулу димера $\underline{68}$ двух карбонильных групп (соединение $\underline{69}$ ) на полярограмме при менее отрицательных потенциалах появляются еще два пика, отражающих восстановление этих групп. Отметим, что каждый из них имеет сложную форму и, вероятно, представляет собой суперпозицию последовательных стадий переноса электрона.<smiles>[R]c1cc([R])c([R])c(-c2cc([R])cc([R])c2[R])c1</smiles>

$$
\begin{aligned}
\underline{66} \mathrm{R} & =\mathrm{R}_{1}=\mathrm{R}_{2}=\mathrm{H} \\
\underline{67} \mathrm{R} & =\mathrm{CH}_{2} \mathrm{OH}, \mathrm{R}_{1}=\mathrm{OMe}, \mathrm{R}_{2}=\mathrm{OH} \\
\underline{68} \mathrm{R} & =\mathrm{CHOHEt}, \mathrm{R}_{1}=\mathrm{OMe}, \mathrm{R}_{2}=\mathrm{OH} \\
\underline{69} \mathrm{R} & =\mathrm{COEt}, \mathrm{R}_{1}=\mathrm{OMe}, \mathrm{R}_{2}=\mathrm{OH}
\end{aligned}
$$

Таблица 15. Полярографические характеристики производных дифенила[29]

\begin{tabular}{c|c|c|c}
\hline Соединение & $-E_{\mathrm{p}}, \mathrm{B}$ & $\mathrm{i}_{\mathrm{p}}$, мкA & $\mathrm{r}$ \\
\hline$\underline{66}$ & 2,50 & 7,2 & - \\
$\underline{67}$ & 2,52 & 1,8 & - \\
$\underline{68}$ & 2,55 & 1,8 & - \\
$\underline{69}$ & 1,94 & 1,2 & - \\
\hline
\end{tabular}

Связи $\beta-5$ и $\beta$ - $\beta$. Соединения, содержащие эти типы связей (흐 и $\underline{65}$ соответственно), полярографически неактивны.

Соединения, содержащчие сопряженные двойные связи

Стильбеновая структура. В неводной апротонной среде (ДМФ) на фоне йодистого тетрабутиламмония транс-стильбен (соединение $\underline{70}$ ) восстанавливается в две последовательные одноэлектронные стадии с $E_{1 / 2}$ соответственно -2,21 В и -2,58 (отн. НКЭ). Первая стадия протекает обратимо, вторая - необратимо [35]. В выбранных условиях (ДМСО, ПТБА) транс-стильбен восстанавливается по аналогичной схеме с $E_{\mathrm{p}}$, соответственно, $-2,14$ В и -2,45 В (табл. 16).

Полярографические характеристики исследованных производных стильбена зависят от характера заместителей. Транс-3,3',4,4'-тетраметоксистильбен (1ㅡ) также восстанавливается в две стадии. По данным ЦВ, первая из них соответствует обратимому переносу одного электрона, вторая - необратима. На полярограмме производного стильбена, содержащего фенольные гидроксильные группы (соединение $\underline{72}$ ), имеется два перекрывающихся пика. Потенциал первого из них составляет $-2,32$ В, потенциал второго определить затруднительно. Вероятно, и в этом случае электрохимическая реакция осложнена влиянием автопротонирования. 
Таблица 16. Полярографические характеристики производных стильбена [29]

\begin{tabular}{c|c|c|c}
\hline Соединение & $-E_{\mathrm{p}}, \mathrm{B}$ & $\mathrm{i}_{\mathrm{p}}$, мкА & $\mathrm{r}$ \\
\hline$\underline{70}$ & 2,14 & 4,4 & + \\
$\underline{71}$ & 2,45 & 3,6 & + \\
& 2,33 & 4,3 & - \\
\hline$\underline{72}$ & 2,64 & 4,4 & - \\
\hline
\end{tabular}

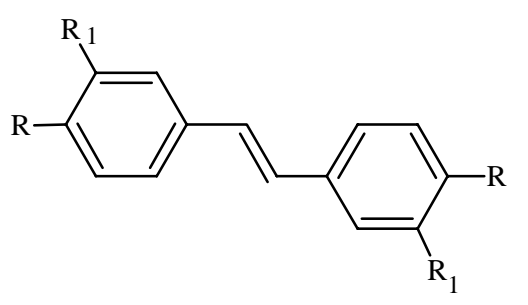

$$
\begin{aligned}
& \underline{70} \mathrm{R}=\mathrm{R}_{1}=\mathrm{H} \\
& \underline{71} \mathrm{R}=\mathrm{R}_{1}=\mathrm{OMe} \\
& \underline{72} \mathrm{R}=\mathrm{OH}, \mathrm{R}_{1}=\mathrm{OMe}
\end{aligned}
$$<smiles>COc1ccc(/C=C\Oc2ccccc2OC)cc1OC</smiles>

Структура энолового эфира. На полярограмме энолового эфира $\underline{73}$ содержится один пик с $E_{\mathrm{p}}=-2,65$ В и $\mathrm{i}_{\mathrm{p}}=7,5$ мкА.

Таким образом, исследование димерных модельных соединений показало, что среди межъединичных связей лигнина полярографической активностью обладают связи $\beta-O-4$ в структурах со смежной карбонильной группой, а также сопряженные двойные связи в структурах типа стильбена и энолового эфира. Кроме того, способностью к электрохимическому восстановлению обладают двойные связи в дифенильных структурах.

По результатам исследования мономерных и димерных модельных соединений построена диаграмма, связывающая строение и реакционную способность структурных фрагментов лигнина при электрохимическом восстановлении (рис. 4).

Сочетание результатов исследования модельных соединений и препаратов лигнина, модифицированных селективными реагентами $\left(\mathrm{NaBH}_{4}, \mathrm{LiAlH}_{4}, \mathrm{CH}_{2} \mathrm{~N}_{2},\left(\mathrm{CH}_{3} \mathrm{O}\right)_{2} \mathrm{SO}_{2}\right)$, позволило идентифицировать пики на дифференциальных импульсных полярограммах лигнина по типам связей и функциональных групп (рис. 5).

Таким образом, из всего многообразия функциональных групп и связей этого полифункционального соединения полярографической активностью обладают карбонильные группы различных типов и сопряженные двойные связи в дифенильных структурах. Избирательность по отношению к альдегидным и кетонным группам лигнина позволяет использовать полярографию для исследования его превращений, затрагивающих указанные группировки.

Хорошим примером использования полярографии для изучения реакций лигнина, протекающих в технологических процессах, является варка целлюлозы в присутствии антрахинона (АХ). Существующие представления о механизмах реакций таких варок изложены в обзоре [52].

Сопоставление полярограмм натронного (контроль) и натронно-антрахинонного лигнинов (рис. 6)

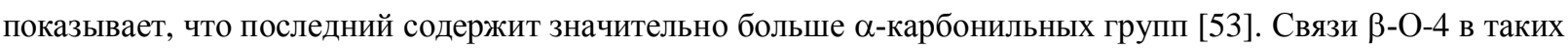
структурах расщепляются в условиях варки значительно быстрее, чем структуры с $\alpha$-спиртовыми группами. В этом просматривается определенная аналогия с электрохимическим расщеплением связи $\beta-\mathrm{O}-4$ (см. выше). На основании этих результатов предложен новый механизм деструкции лигнина при варках в присутствии AX $[54,55]$. Кроме того, сопоставление редокс-свойств лигнина и производных АХ позволило сформулировать критерии отбора катализаторов щелочной делигнификации древесины [56, 57].

Еще одним примером использования электрохимии в химии лигнина является изучение роли продукта одноэлектронного восстановления $\mathrm{AX}$ - антрасемихинона (ACX) - в расщеплении связей $\beta$-O-4 лигнина при натронно-антрахинонных варках. Согласно традиционной точке зрения [52], ключевая роль здесь принадлежит продукту полного восстановления АХ - антрагидрохинону (АГХ), образующему аддукт с хинонметидными структурами лигнина. Однако имеется и альтернативная точка зрения, согласно которой имеет место реакция с переносом электрона с участием АСХ [40]. Методом ЦВА показано, что элек- 
трохимическое восстановление системы $\mathrm{AX}$-хинонметид приводит к появлению каталитического тока. Иными словами, восстановление хинонметида (XM) происходит путем переноса электрона с $\mathrm{ACX}$, а не непосредственно с катода (уравнения 18, 19).

Методом ЦВА нами исследованы хинонметиды 30-36 [30]. В результате установлено, что каталитический ток появляется лишь в том случае, если ХМ содержит связь $\beta-\mathrm{O}-4$, а именно в случае восстановления XМ $\underline{33}$-35. В качестве примера на рисунке 7 приведены циклические вольтамперограммы АХ, ХM $\underline{35}$ и их смесей с увеличивающимся содержанием ХМ.

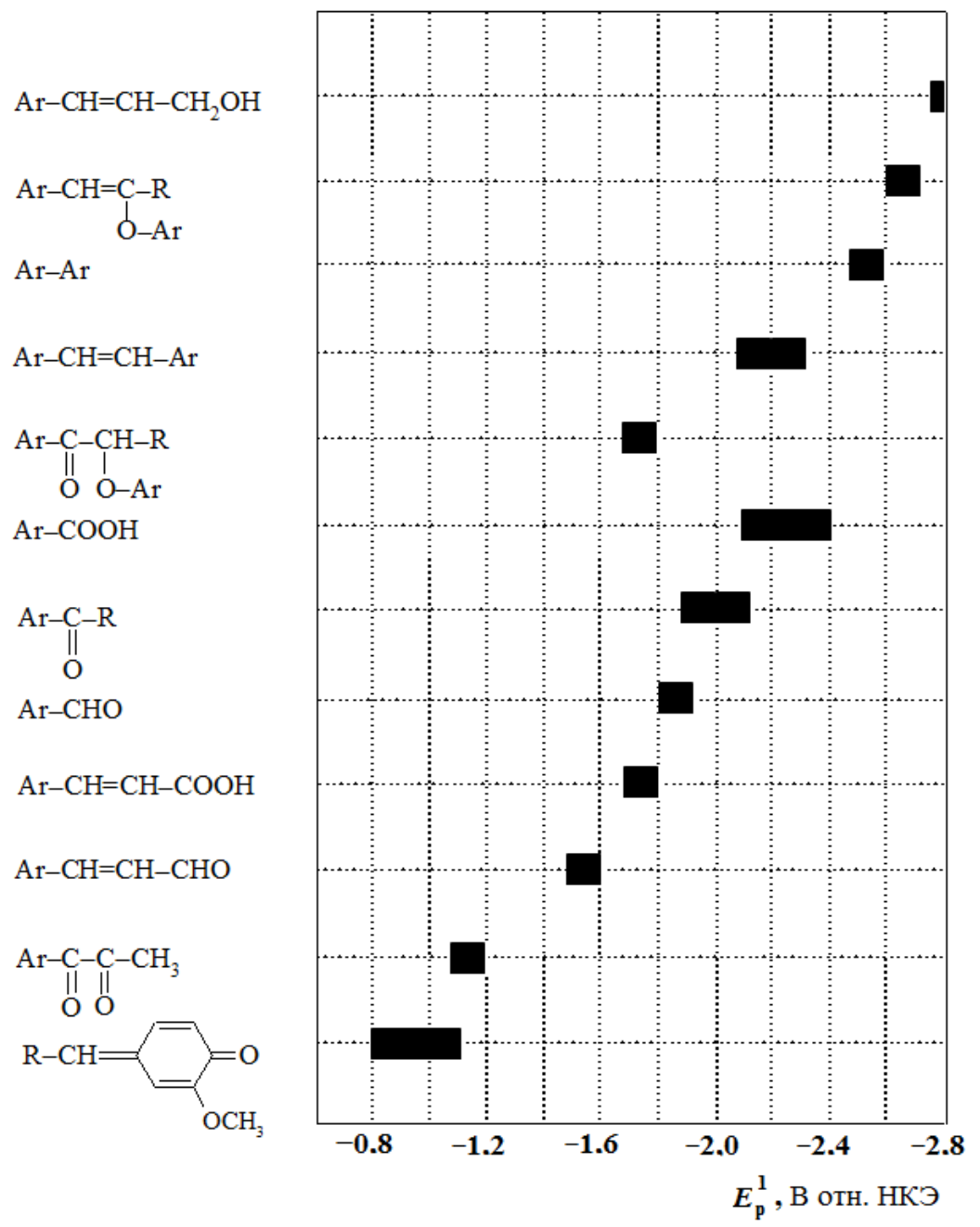

Рис. 4. Диаграмма потенциалов восстановления полярографически активных функциональных групп и связей модельных соединений лигнина. ДМСО на фоне перхлората тетрабутиламмония [29]

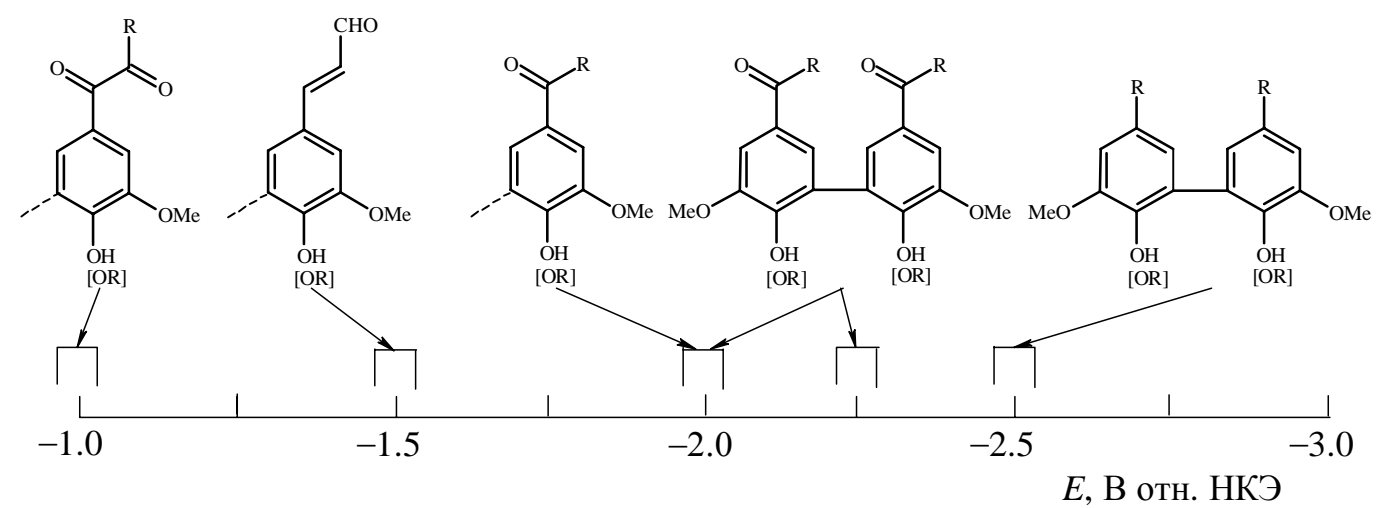

Рис. 5. Диаграмма потенциалов восстановления полярографически активных функциональных групп и связей лигнина [29] 
Рис. 6. Полярограммы натронно-антрахинонного (1) и натронного (2) лигнинов в ДМСО на фоне перхлората тетрабутиламмония (3) [53]
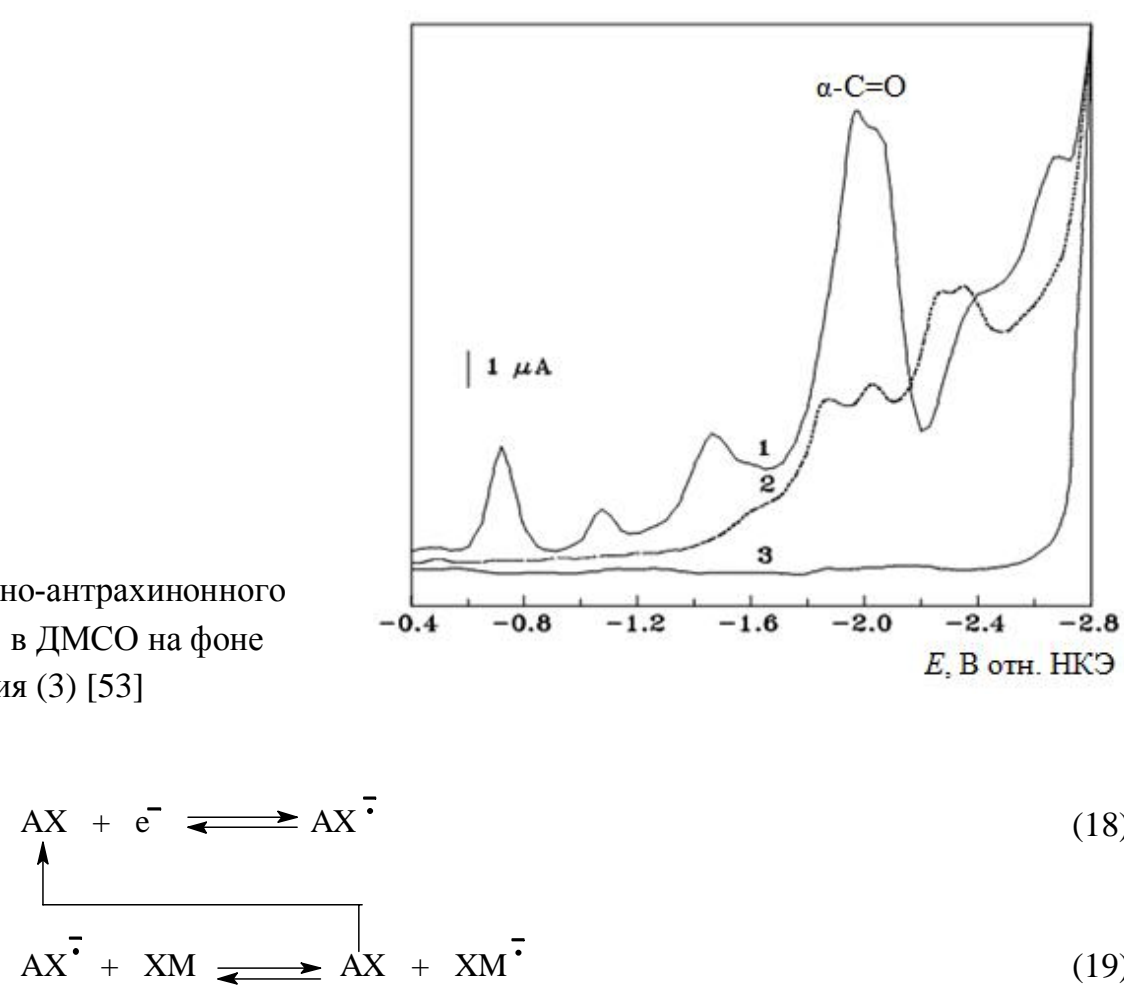

Рис. 7. Циклические вольтамперограммы АХ и хинонметида $\underline{35}$ в системе ДМСО- $\mathrm{CH}_{2} \mathrm{Cl}_{2}(9: 1)$ на платиновом электроде. Скорость развертки 200 мB/c. 1 - XM, 2 - AX, 3 и 4 AX + XМ.

Концентрация (моль/л) АХ во всех опытах $0,48 \cdot 10^{-3}$, ХМ: 1 и $3-0,95 \cdot 10^{-3}, 4-1,74 \cdot 10^{-3}[30]$

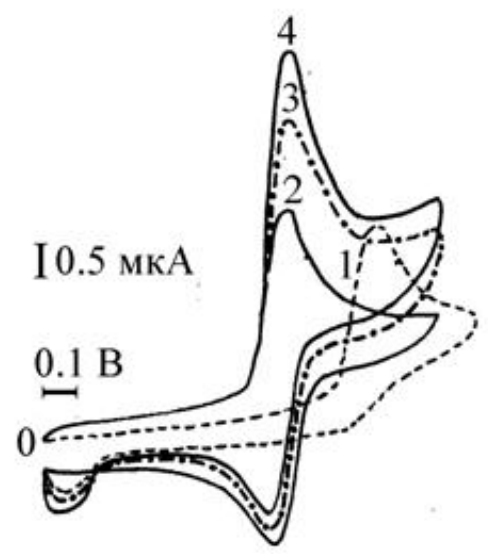

Препаративный электролиз смесей АХ и ХМ, содержащего связь $\beta-\mathrm{O}-4$, приводит к расщеплению этой связи [40]. Об образовании АСХ в этой системе свидетельствуют данные ЭПР-спектроскопии [58]. Кроме того установлено, что существует взаимосвязь между константой образования АСХ и эффективностью катализатора при варке [59]. Совокупность полученных результатов позволяет считать АСХ каталитически активной промежуточной частицей в реакциях лигнина и АХ в условиях щелочных варок древесины.

Препаративное электрохимическое восстановление лигнина и модельных соединений проводилось в работах Чупки с соавторами [60-67] с использованием как прямого (на катодах из ртути и других металлов), так и непрямого (амальгамами щелочных металлов) восстановления. Наиболее важными, на наш взгляд, результатами являются следующие. В мономерных модельных соединениях происходит восстановление сопряженных карбонильных групп и двойных связей, а также их димеризация. Лигнин в этих условиях подвергается восстановительному расщеплению с образованием низкомолекулярных продуктов, причем обратного процесса - увеличения молекулярной массы - не наблюдается.

Особый интерес представляет работа [63], в которой установлено, что в результате препаративного электролиза лигнина в ДМФ при потенциале -2,6 В относительно НКЭ в течение 4 ч на полярограмме лиг- 
нина почти полностью исчезает волна с $E_{1 / 2}-2,72$ В и одновременно значительно увеличивается высота волны с $E_{1 / 2}-2,17 \mathrm{~B}$. Авторы не обсуждают причины отмеченного явления.

Можно предложить, что схема превращений лигнина в этих условиях включает в себя реакции восстановления с образованием анион-радикалов в отдельных структурных фрагментах с их последующей деструкцией до радикального и анионного фрагментов.

Это можно проиллюстрировать, записав уравнение 19, с помощью структурных формул<smiles>C/C=C/c1ccc(O)c(OC)c1</smiles>

Можно заметить, что ХМ после переноса электрона от АCX превращается в анион-радикал, распадающийся на анион (гваякол) и радикал (изоэвгенол). На последующей стадии радикал принимает электрон от АСХ, образуя соответствующий анион. Оба соединения выделены в нейтральной форме, и их строение доказано методом хроматомасс-спектрометрии [40].

В апротонном растворителе лигнин обладает полярографической активностью в широком диапазоне потенциалов (рис. 3), поэтому если вести электролиз при потенциале вблизи от точки разряда фонового электролита, реакция будет проходить одновременно по нескольким реакционным центрам с образованием анион-радикалов. Вполне вероятно, что их распад происходит по рассмотренной схеме деструкции димерного ХМ, только роль АСХ выполняет электрод. Это объясняет, почему в процессе электролиза растет предельный ток волны с $E_{112}-2,17$ В. В результате электрохимической деструкции лигнина образуются низкомолекулярные полярографически активные соединения, обладающие значительно более высокими значениями коэффициента диффузии. Полимеризации фрагментов, содержащих анион-радикальные и радикальные реакционные центры, препятствуют пространственные затруднения вокруг них. К тому же при наличии в деполяризаторе большого числа электроноакцепторных групп становится возможным электрохимическое расщепление прилегающих к ним углерод-углеродных связей [11]. Лигнин относится именно к такому типу соединений.

\section{Анодные реакции}

\section{Окисление в водных средах}

Первое упоминание об электрохимическом окислении лигнина относится к 1921 г. [68]. При окислении лигносульфонатов бария на платиновом аноде в растворе разбавленной серной кислоты предположительно образуются ванилин и янтарная кислота (цитировано по [69]). В результате окисления хвойного бутаноллигнина в 1\%-ном растворе $\mathrm{NaOH}$ на свинцовом аноде образуется 81,6\% низкомолекулярных соединений и среди них следующие кислоты: уксусная, резорциловая, протокатеховая, $n$-гидроксибензойная, толуиловая и щавелевая [70]. Высокий выход низкомолекулярных продуктов окисления свидетельствует о глубокой деструкции лигнина в этих условиях, однако бутаноллигнин представляет собой лишь небольшую низкомолекулярную фракцию природного лигнина. 
Механизм окисления фенолов является функцией $\mathrm{pH}$. При $\mathrm{pH}<\mathrm{pK}$ ароисходит перенос двух электронов, при $\mathrm{pH}>\mathrm{pK}_{\mathrm{a}}$ - одного [71-74]. Например, для ванилина предложены следующие реакции (уравнения 20, 21) [75]:<smiles>COc1cc(C=O)ccc1O</smiles><smiles>CCCCC1C=C(C=O)C=C(OC)C1=O</smiles>

Реакционную способность при электрохимическом окислении отдельных фрагментов и всей молекулы лигнина можно оценить, сопоставляя данные таблицы 17. Изучение концентрационных зависимостей предельного тока и другие тесты показали, что волны окисления имеют диффузионный характер и соответствуют необратимому переносу двух электронов [72, 73].

Судя по приведенным потенциалам, лигнин и модельные соединения, не содержащие электроноакцепторных групп, относительно легко окисляются на электроде в диапазоне от 0 до 0,45 В. Отчетливо про-

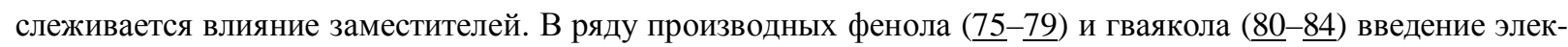
тронодонорных заместителей, особенно в орто-положении к фенольному гидроксилу, заметно снижает $E_{1 / 2}$. Ароматические альдегиды, кетоны и кислоты окисляются значительно трудней, например $E_{1 / 2}$ соединений $\underline{85}, \underline{90}$ и $\underline{100}$ составляют, соответственно, $0 ; 63 ; 0,73$ и 0,53 В. При увеличении в ароматическом кольце числа электронодонорных заместителей в ряду этих групп соединений потенциал окисления уменьшается вплоть до $E_{1 / 2}=0,08$ В (соединение 97). Здесь также особенно заметно влияние заместителей в смежных положениях к фенольному гидроксилу: в соединении $\underline{97}$ в этих положениях находятся метоксильные группы. Сопряжение двойной связи в боковой цепи с бензольным кольцом облегчает окисление (соединения $\underline{102}, \underline{103})$.

Таблица 17. Потенциалы окисления лигнина [72], модельных и родственных соединений [76] на вращающемся электроде (спектральный графит) в 0,5 н. растворе $\mathrm{Na}_{2} \mathrm{HPO}_{4}$

\begin{tabular}{|c|c|c|}
\hline \multicolumn{2}{|c|}{ Соединение } & $E_{1 / 2}, \mathrm{~B}$, отн. НКЭ \\
\hline 1 & $\underline{2}$ & 3 \\
\hline $\mathrm{R}_{1}$ & $\begin{array}{c}\underline{74} \mathrm{R}_{1}=\mathrm{R}_{1}=\mathrm{R}_{2},=\mathrm{R}_{3}=\mathrm{R}_{4}=\mathrm{H} \\
\underline{75} \mathrm{R}_{1}=\mathrm{Me}, \mathrm{R}_{2}=\mathrm{R}_{3}=\mathrm{R}_{4}=\mathrm{H} \\
\underline{76} \mathrm{R}_{1}=\mathrm{H}, \mathrm{R}_{2}=\mathrm{Me}, \mathrm{R}_{3}=\mathrm{R}_{4}=\mathrm{H} \\
\underline{77} \mathrm{R}_{1}=\mathrm{R}_{2}=\mathrm{Me}, \mathrm{R}_{3}=\mathrm{R}_{4}=\mathrm{H} \\
\underline{78} \mathrm{R}_{1}=\mathrm{H}, \mathrm{R}_{2}=\mathrm{R}_{3}=\mathrm{Me}, \mathrm{R}_{4}=\mathrm{H} \\
\underline{79} \mathrm{R}_{1}=\mathrm{R}_{2}=\mathrm{R}_{3}=\mathrm{H}, \mathrm{R}_{4}=\mathrm{OH}\end{array}$ & $\begin{array}{l}0,45 \\
0,28 \\
0,41 \\
0,20 \\
0,36 \\
0,00\end{array}$ \\
\hline $\mathrm{R}_{1}$ & $\begin{array}{c}\underline{80} \mathrm{R}_{1}=\mathrm{R}_{2}=\mathrm{R}_{3}=\mathrm{H}, \mathrm{R}_{4}=\mathrm{OMe} \\
\underline{81} \mathrm{R}_{1}=\mathrm{H}, \mathrm{R}_{2}=\mathrm{Me}, \mathrm{R}_{3}=\mathrm{H}, \mathrm{R}_{4}=\mathrm{OMe} \\
\underline{82} \mathrm{R}_{1}=\mathrm{H}, \mathrm{R}_{2}=\mathrm{Et}, \mathrm{R}_{3}=\mathrm{H}, \mathrm{R}_{4}=\mathrm{OME} \\
\underline{83} \mathrm{R}_{1}=\mathrm{OMe}, \mathrm{R}_{2}=\mathrm{R}_{3}=\mathrm{H}, \mathrm{R}_{4}=\mathrm{OMe} \\
\underline{84} \mathrm{R}_{1}=\mathrm{OMe}, \mathrm{R}_{2}=\mathrm{Et}, \mathrm{R}_{3}=\mathrm{OMe}, \mathrm{R}_{4}=\mathrm{H}\end{array}$ & $\begin{array}{l}0,25 \\
0,19 \\
0,22 \\
0,19 \\
0,18\end{array}$ \\
\hline$\overbrace{\mathrm{OH}}^{\mathrm{N}}$ & $\begin{array}{c}\underline{85} \mathrm{R}_{1}=\mathrm{R}_{2}=\mathrm{R}_{3}=\mathrm{H} \\
\underline{86} \mathrm{R}_{1}=\mathrm{R}_{2}=\mathrm{H}, \mathrm{R}_{3}=\mathrm{OMe} \\
\underline{87} \mathrm{R}_{1}=\mathrm{OMe}, \mathrm{R}_{2}=\mathrm{H}, \mathrm{R}_{3}=\mathrm{OMe} \\
\underline{88} \mathrm{R}_{1}=\mathrm{COOH}, \mathrm{R}_{2}=\mathrm{H}, \mathrm{R}_{3}=\mathrm{OMe} \\
\underline{89} \mathrm{R}_{1}=\mathrm{CHO}, \mathrm{R}_{2}=\mathrm{H}, \mathrm{R}_{3}=\mathrm{OMe}\end{array}$ & $\begin{array}{l}0,63 \\
0,48 \\
0,32 \\
0,45 \\
0,56\end{array}$ \\
\hline
\end{tabular}


Окончание таблицьь 17

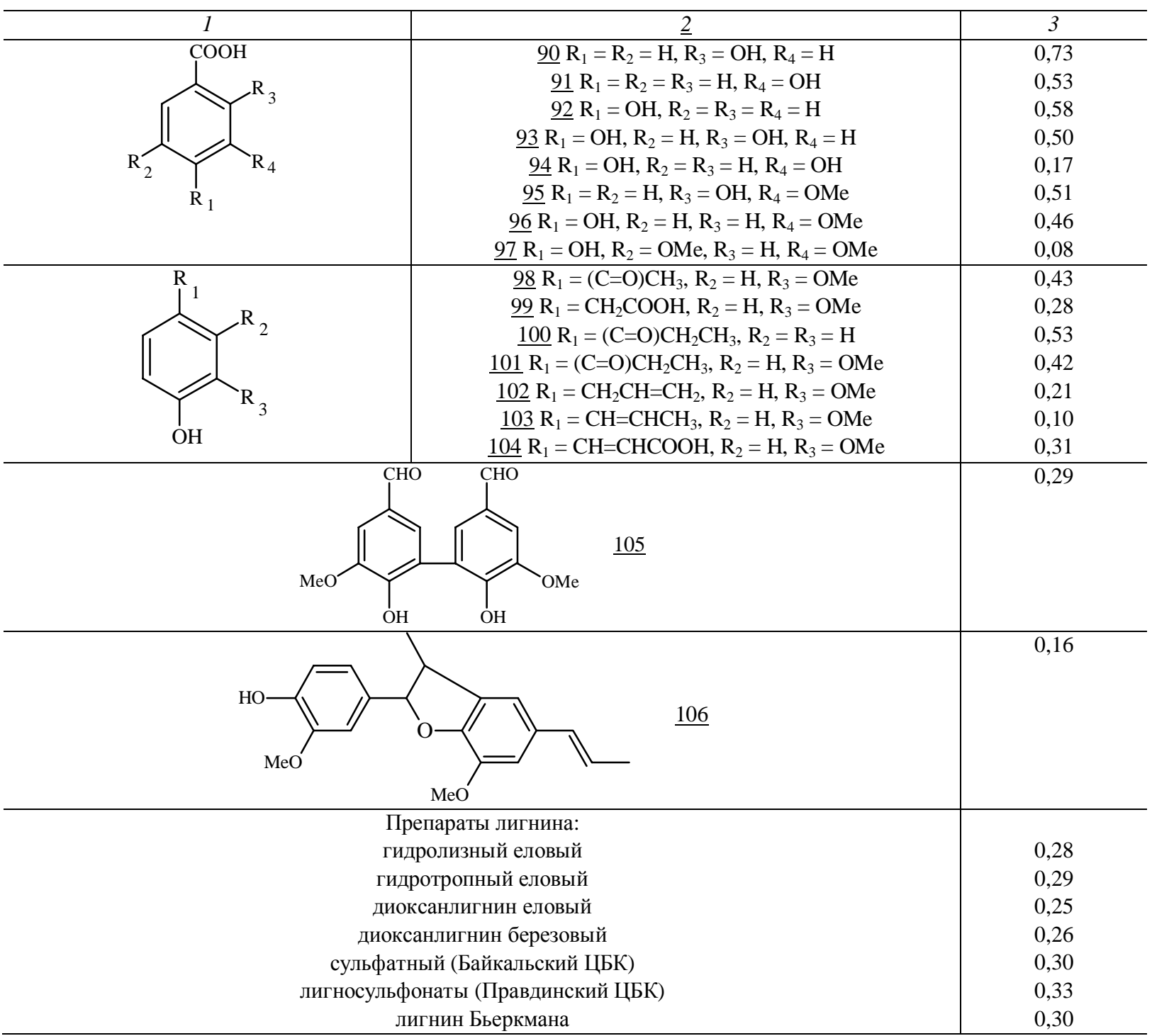

В ряду соединений $\underline{74}$ (фенол), $\underline{80}$ (гваякол) и $\underline{83}$ (сирингол) потенциал окисления заметно уменьшается. Если считать эти фенолы простейшими моделями реакционных центров электрохимического окисления лигнина, то можно ожидать более легкой окисляемости при переходе от лигнина однолетних растений к хвойному и далее лиственному лигнину.

Наличие на вольтамперограммах препаратов лигнина различного происхождения только одной волны окисления в достаточно узком диапазоне значений $E_{1 / 2}$ от 0,25 до 0,33 В означает, что его реакционными центрами являются ароматические кольца. Значения $E_{1 / 2}$ димеров 105 и 106 также укладываются в указанный диапазон потенциалов.

В монографии [77] и статьях [78-87] приведены потенциалы окисления и некоторых других модельных соединений, однако отличающиеся условия экспериментов (электроды, фоновые электролиты, растворители) не позволяют использовать их для корреляций в ряду обсуждавшихся соединений в таблице 17. В указанной монографии содержатся также сведения о влиянии сольватации на электрохимические реакции.

Электрохимическое окисление модельных соединений в кислой среде показало, что направление реакции зависит от того, каким является фенольный гидроксил - свободным или блокированным [88]. В результате электролиза изоэвгенола $(\underline{103})$ на свинцовом аноде в 2 н $\mathrm{H}_{2} \mathrm{SO}_{4}$ образуется ванилин $(\underline{86})$ с выходом $14 \%$, а основная часть полученных продуктов представляет собой «смолу». Такие же результаты получены при окислении пропилгваякола, за исключением того, что в небольших количествах образуется продукт димеризации этого фенола. По-видимому, и в этих условиях при окислении происходит перенос одного электрона и одного протона, а образующиеся феноксильные радикалы димеризуются. 
На наш взгляд, здесь прослеживается определенная аналогия между электрохимическим и ферментативным окислением предшественников лигнина в процессе биосинтеза. Как известно [89], такими предшественниками являются $n$-гидроксикоричные спирты, а образование молекул лигнина можно рассматривать как дегидрогенизационную полимеризацию. Для кониферилового спирта начальная стадия описывается следующей схемой:

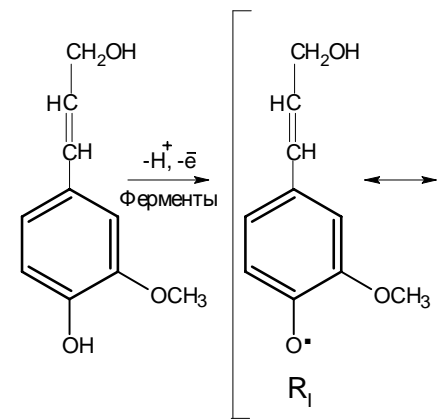<smiles>[R7]OC1=CC(=CC(C)CO)C=CC1=O</smiles><smiles>[R]OC1=CC(=CCO)C=CC1=O</smiles><smiles>[R]OC1C=C(C=CCO)C=CC1=O</smiles>

Далее происходит рекомбинация феноксильных радикалов в различных положениях и после стабилизации промежуточных хинонметидов образуются димеры и тримеры, которые под действием ферментов снова дают феноксильные радикалы, взаимодействующие с мономерами, димерами и тримерами, и таким образом формируется молекула лигнина. Аналогия с электрохимическим окислением состоит в том, что в обоих случаях сочетание радикалов ферментативно не контролируется. Отсюда - многообразие типов связей между ФПЕ и нерегулярность строения лигнина.

При окислении в тех же условиях [88] изоэвгенола с этерифицированным фенольным гидроксилом выделено 57,4\% ванилина (하) и 25,7\% ванилиновой кислоты (96). В результате электролитического окисления 3,4-диметоксипропенилбензола (107) образуется 77,8\% вератрового альдегида $(\underline{108)})$ и $12,7 \%$ вератровой кислоты (109). Из 4-метоксипропенилбензола $(\underline{110})$ образуется 52\% анисового альдегида $(\underline{111})$ и $25,4 \%$ анисовой кислоты (112). По мнению авторов, все эти данные свидетельствуют об определяющем значении в образовании смол фенольных гидроксилов, а не сопряженных двойных связей.<smiles>C/C=C/c1ccc(OC)c(OC)c1</smiles>

107<smiles>COc1ccc(C=O)cc1OC</smiles>

$\underline{108}$<smiles>COc1ccc(C(=O)O)cc1OC</smiles>

109<smiles>C/C=C/c1ccc(OC)cc1</smiles>

$\underline{110}$<smiles>COc1ccc(C=O)cc1</smiles><smiles>COc1ccc(C(=O)O)cc1</smiles>

$\underline{111}$

Отметим и такой факт: при электрохимическом окислении 1,2-диметоксибензола в разбавленной серной кислоте в качестве основного продукта образуется янтарная кислота (НОOC- $\left.\mathrm{CH}_{2}-\mathrm{CH}_{2}-\mathrm{COOH}\right)$ [90].

Таким образом, в результате электрохимического окисления нефенольных структурных фрагментов лигнина в кислой среде может происходить отщепление боковых пропановых цепей, образование ароматических альдегидов и кислот, а возможно, и расщепление ароматического кольца, т.е. глубокая деструкция. По аналогии с химическим окислением относительно простых алкилариловых эфиров [91] можно также ожидать деметилирование и окисление этих фрагментов до соответствующих хинонов. Фенольные фрагменты в этих условиях склонны к реакциям полимеризации.

\section{Окисление в ацетонитриле}

Изучение механизмов реакций электрохимического окисления модельных соединений в неводной и водно-органических средах проводилось преимущественно в ацетонитриле. Широкий диапазон доступных потенциалов при анодной поляризации платинового электрода (вплоть до 2 В), растворимость в нем органических и неорганических соединений и способность смешиваться с водой сделали ацетонитрил наиболее распространенным растворителем в области электрохимического окисления [92]. 
При окислении в безводном ацетонитриле на вращающемся платиновом электроде 3,4-диметоксипропенилбензол (107) п проявляет три волны с $E_{1 / 2}$ соответственно 0,98, 1,2 и 1,4 В отн. НКЭ (рис. 8) [69]. Подробно исследована природа первой волны. На основании вольтамперометрических измерений, включающих в себя определение обратимости процесса, числа переносимых электронов и изучения строения продуктов препаративного электролиза, она интерпретируется как диффузионная, одноэлектронная, электрохимически обратимая, отвечающая образованию катион-радикала. Предполагаемый механизм протекающих реакций приведен на рисунке 9.

Образующиеся на первой стадии катион-радикалы (B) димеризуются в положении $\beta-\beta$ боковой цепи (димер C) с последующей стабилизацией промежуточного соединения (D) за счет элиминирования протона и замыкания цикла. Стабилизация продукта реакции (Е) может происходить при взаимодействии с нуклеофилами, например с перхлорат-анионом.

Автор отмечает, что стабилизация катион-радикалов может происходить различными путями, такими как димеризация, фрагментация, присоединение радикалов или нуклеофилов, но, судя по составу продуктов электролиза, реализуется описанный механизм.

Потенциалы и предельные токи второй и третьей волн плохо воспроизводятся, а вольтамперные характеристики зависят от концентрации деполяризатора и способа предварительной обработки поверхности рабочего электрода, и поэтому они подробно не изучались. Не исключается дальнейшее окисление стабилизированного продукта (Е).

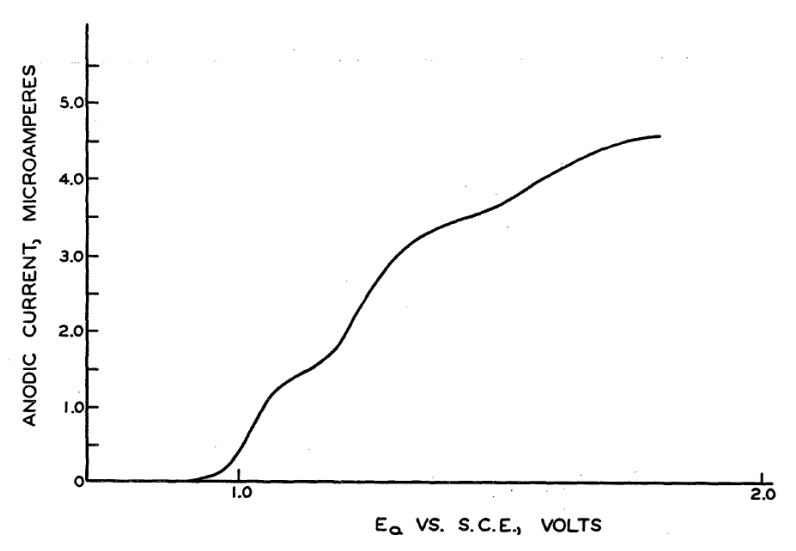

Рис. 8. Вольтамперограмма 3,4-диметоксипропенилбензола (107) на вращающемся платиновом электроде в ацетонитриле на фоне 0,5 $\mathrm{M}$ раствора $\mathrm{NaClO}_{4}[69]$<smiles>COc1ccc(/C=C/C(C)=C/C(C)CCc2ccc(OC)c(OC)c2)cc1OC</smiles><smiles>COc1ccc(C2c3cc(OC)c(OC)cc3[CH-]C(C)C2C)cc1OC</smiles>

E<smiles>COC1=C[C+](Cc2ccc(OC)c(OC)c2)C([CH-]C(C)C)=CC1=O</smiles>

D<smiles>COc1ccc([CH+]C(C)C(C)Cc2ccc(OC)c(OC)c2)cc1OC</smiles>

C

Рис. 9. Предполагаемый механизм реакции электрохимического окисления 3,4-диметоксипропенилбензола (107) в ацетонитриле [69] 
В присутствии органического основания (пиридина) при окислении соединения (107) в ацетонитриле наблюдается одна двухэлектронная необратимая волна при потенциале, близком $E_{1 / 2}$ в безводном ацетонитриле. В результате препаративного электролиза при этом потенциале с почти количественным выходом выделен продукт замещения в $\alpha, \beta$-положениях боковой цепи - дипиридиниумдиперхлорат соединения (107).

Методами циклической вольтамперометрии, препаративного электролиза, ЭПР- и УФ-спектроскопии исследовано окисление гидрохинона, гваякола и пропилгваякола в безводном ацетонитриле на фоне $\mathrm{LiClO}_{4}[93,94]$. Установлено, что на первой стадии процесса окисления происходит образование катионрадикалов с последующей очень быстрой реакцией их депротонизации и полимеризации. В присутствии воды промежуточные радикалы окисляются далее до соответствующих хинонов, деметилирования при этом не происходит. Для гваякола и пропилгваякола предложена следующая схема превращений. Димеры и хиноны выделены и охарактеризованы.

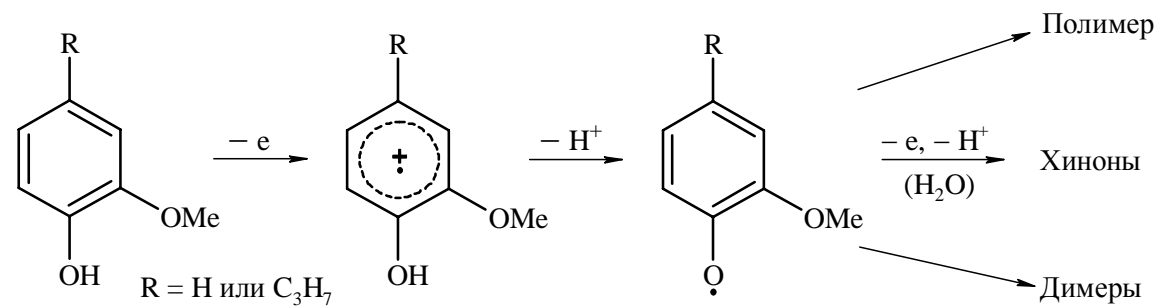

Увеличение объемной доли воды в системе вода : ацетонитрил до $80 \%$ приводит к изменению механизма окисления гваякола и других замещенных фенолов до двухэлектронного, описываемого уравнением 20. Кроме того, в продуктах окисления ванилинового спирта качественно доказано присутствие ванилина, т.е. в этих условиях возможно окисление $\alpha$-спиртовых групп [95].

Прямого электрохимического окисления $\alpha$-спиртовых групп до карбонильных в нефенольных модельных соединениях, таких как 1-(4-этокси-3-метоксифенил)этанол (113) и 4-этокси-3-метоксифенилглицерин- $\beta$-гваяциловый эфир (1ㄴ) в ацетонитриле на платиновом электроде в 0,1 М растворе $\mathrm{LiClO}_{4}$ не происходит $[96,97]$. Электролиз димера $\underline{114}$ в этих условиях вызывает расщепление связи $\mathrm{C}_{\alpha}-$ $\mathrm{C}_{\beta}$, о чем свидетельствует образование с 40\%-ным выходом 4-О-этилванилина.<smiles>CCOc1ccc(C(C)O)cc1OC</smiles>

$\underline{113}$<smiles>CCOc1ccc(C(O)C(CO)Oc2ccccc2OC)cc1OC</smiles>

$\underline{114}$

Электролиз в присутствии $N$-гидроксифталимида приводит к получению из указанных моделей соответствующих $\alpha$-карбонилсодержащих соединений с выходом 95-97\%. По мнению авторов, в данном случае происходит непрямое окисление за счет переноса атома водорода на молекулу $N$-гидроксифталимида, играющего роль медиатора.

Механизм реакции электрохимической деструкции наиболее распространенной в лигнине связи $\beta-\mathrm{O}-4$ исследован в безводном и 50\%-ном водном растворах ацетонитрила на платиновом вращающемся дисковом электроде. Фоновый электролит - $\mathrm{LiClO}_{4}$ [98]. На вольтамперограмме $\beta$-гваяцилового эфира вератрилпропанона-1 (60) наблюдаются три плохо разделенные волны окисления с $E_{1 / 2} 1,45,1,63$ и 1,91 В относительно электрода сравнения $\mathrm{Ag} / 0,01 \mathrm{M} \mathrm{AgNO}_{3}$, В водном ацетонитриле проявляется одна волна с $E_{1 / 2} 1,32 \mathrm{~B}$.

В продуктах препаративного электролиза димера $\underline{60}$ в ацетонитриле идентифицированы гваякол

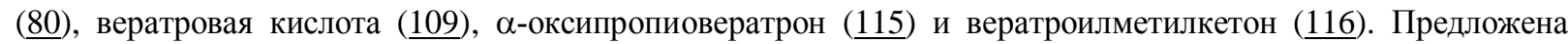
схема, в соответствии с которой на первой стадии происходит обратимый перенос одного электрона с образованием катион-радикала, за которым следует достаточно сложная цепь превращений, в результате чего происходит расщепление связи $\beta-\mathrm{O}-4$. 
<smiles>COc1ccccc1OC(C)C(=O)c1ccc(OC)c(C(=O)C(C)Oc2ccccc2OC)c1</smiles>

$\underline{60}$<smiles>COc1ccc(C(=O)C(=O)O)cc1OC</smiles>

По нашему мнению, здесь возможны также и непосредственная фрагментация катион-радикала на ионный и радикальный фрагменты, и их последующие реакции как на электроде, так и в растворе, подобно тому как это происходит при фрагментации анион-радикала хинонметида (см. уравнение 19, записанное с помощью структурных формул). На такую возможность указывает образование гваякола, однако указанное предположение требует экспериментальной проверки.

Способность димеров, содержащих различные типы связей между ФПЕ, к анодному окислению в ацетонитриле исследована в широком ряду модельных соединений (табл. 18) [51]. Строить корреляции в этом ряду достаточно сложно, поскольку соединения отличаются друг от друга не одним, а несколькими заместителями, различающимися донорно-акцепторными свойствами. Поэтому можно сделать лишь самые общие выводы относительно их реакционной способности. Судя по потенциалам окисления, димеры, со-

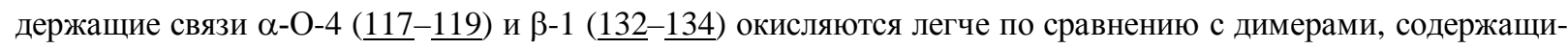
ми связь $\beta-\mathrm{O}-4$, Электронодонорные заместители облегчают, а электроноакцепторные затрудняют окисление. Димер, содержащий связь $\beta-\mathrm{O}-4$ и гидроксильную группу в $\alpha$-положении боковой цепи, имеет $E_{1 / 2}=$ 1,07 В (в табл. 18 не приведен).

Как отмечают авторы, волны окисления необратимы, плохо выражены и соответствуют переносу нескольких электронов. К одноэлектронному окислению способны димеры, содержащие фенольные гидроксилы, в присутствии катион-радикала $n$-трибромтрифениламина, однако в условиях препаративного окисления в его присутствии образуются продукты полимерного характера, образующие на электроде пленку. Помимо указанных в таблице 18 соединений, исследованы также димеры 105 и $\underline{106}$ (табл. 17), имеющие $E_{1 / 2} 1,04$ и 0,72 В соответственно. Если привести эти потенциалы к НКЭ с помощью поправки, приведенной в [92], то они составят 0,78 и 0,46 В. Такой сравнительный анализ показывает, насколько устойчивее к окислению соединения в нейтральном растворителе по сравнению со слабощелочным (рН 0,5 н. раствора $\mathrm{Na}_{2} \mathrm{HPO}_{4}$ составляет 9).

Подводя итоги изучения электрохимического окисления модельных соединений лигнина, можно сделать следующие выводы. Реакционными центрами лигнина в таких реакциях являются ароматические кольца. При окислении в щелочной среде фенольные фрагменты макромолекулы окисляются до феноксильных радикалов, вступающих в реакции димеризации и полимеризации. В кислой и нейтральной средах (до $\mathrm{pH}<\mathrm{pK}_{\mathrm{a}}$ ) они вступают в реакции деметилирования и окисления до хинонов. В растворах с высокой кислотностью, например растворах $\mathrm{H}_{2} \mathrm{SO}_{4}$, указанные структуры, как насыщенные в боковой цепи, так и ненасыщенные, при окислении образуют смолообразные продукты.

Нефенольные структурные фрагменты при окислении в кислых и неводных средах, например в ацетонитриле, подвергаются глубокой деструкции, включающей в себя расщепление алкиларильных простых эфирных связей, отщепление боковых пропановых цепей, а также образование ароматических альдегидов, кетонов и кислот.

При наличии в боковой цепи сопряженной двойной связи они способны димеризоваться. Не исключается также возможность раскрытия ароматического кольца. 
Таблица 18. Потенциалы окисления димерных модельных соединений лигнина на вращающемся платиновом электроде в ацетонитриле на фоне $0,1 \mathrm{M} \mathrm{LiClO}_{4}$ отн. $\mathrm{Ag} / 0,01 \mathrm{M} \mathrm{Ag}^{+}$[51]

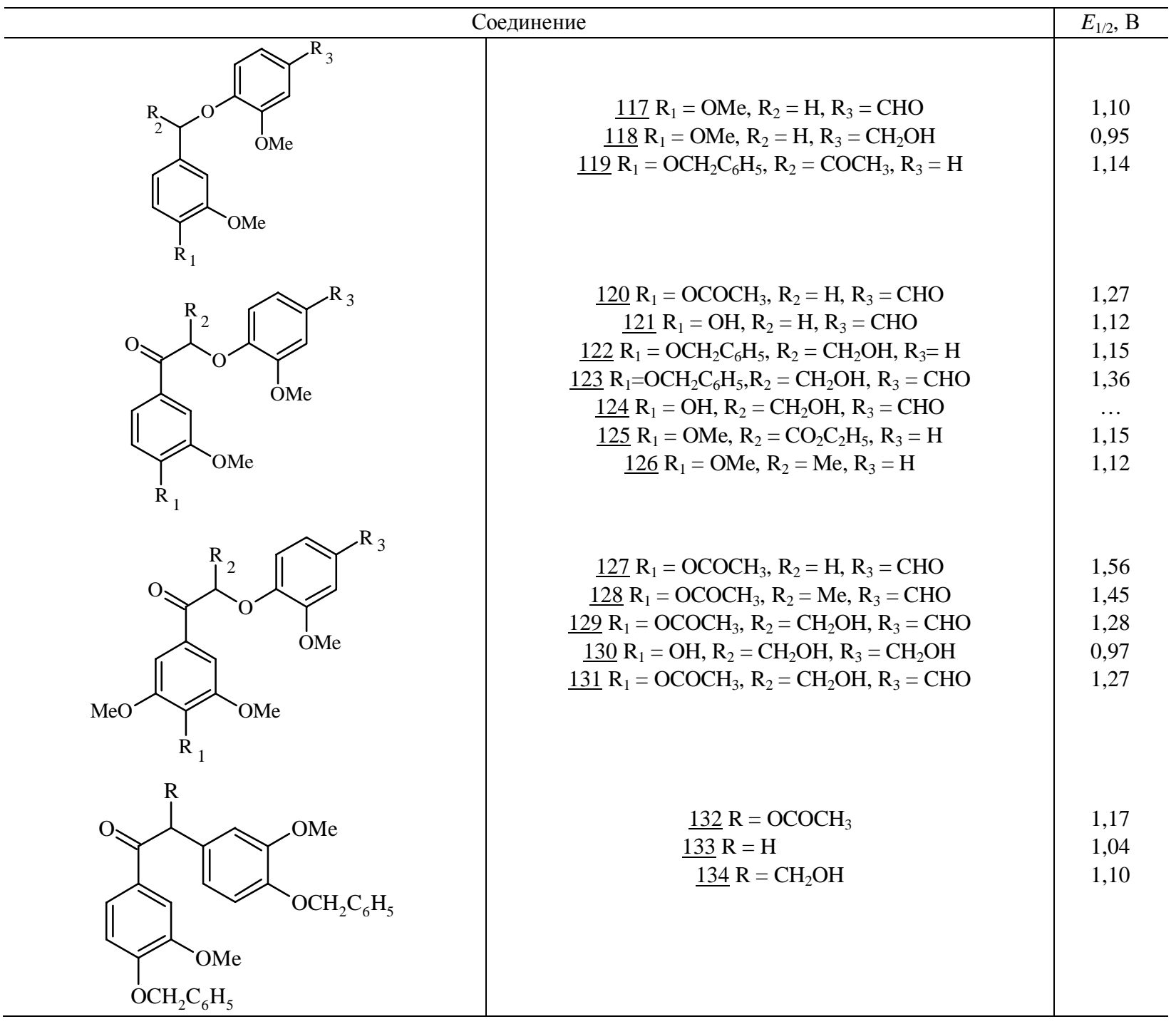

Препаративное окисление лигнина

Препаративный электролиз растворов сульфатного хвойного (сосна) и лиственного (береза) лигнина в $1 \mathrm{M} \mathrm{NaOH} \mathrm{на} \mathrm{платиновом} \mathrm{электроде} \mathrm{(пластина} \mathrm{30×40} \mathrm{мм)} \mathrm{при} \mathrm{потенциале} \mathrm{0,5} \mathrm{В} \mathrm{отн.} \mathrm{НКЭ} \mathrm{исследован}$ в работе [99]. Продукты электролиза осаждались из анолита кислотой и анализировались с использованием ИК- и УФ-спектроскопии, гель-проникающей хроматографии, кислотно-основного титрования и элементного анализа.

Даже при низкой концентрации лигнина $\left(0,5 \Gamma^{-\pi^{-1}}\right)$ продолжительность электролиза составляла не менее 5 ч, поскольку на поверхности электрода образовывалась пленка, состоящая из продуктов реакции. В поисках средств решения возникшей проблемы через раствор барботировали кислород, однако более эффективным оказалось использование переносчика электронов - ферроцианида калия, т.е. непрямое электрохимическое окисление. При этом протекали следующие реакции:

$$
\text { на электроде: } \mathrm{Fe}(\mathrm{CN})_{6}{ }^{-4}-\mathrm{e} \rightarrow \mathrm{Fe}(\mathrm{CN})_{6}{ }^{-3} \text {, }
$$

в растворе: $\mathrm{Fe}(\mathrm{CN})_{6}^{-3}+$ лигнин $\rightarrow \mathrm{Fe}(\mathrm{CN})_{6}^{-4}+$ окисленный лигнин.

Доказательством протекания именно этих реакций является появление каталитической волны на вольтамперограмме ферроцианида калия в присутствии лигнина. Такой подход позволил увеличить концентрацию лигнина до 4 г·л ${ }^{-1}$ без образования пленки. 
Выход осаждающихся из раствора продуктов окисления в этих условиях $\left(\mathrm{O}_{2}+\mathrm{Fe}(\mathrm{CN})_{6}^{-4}\right)$ для лиственного лигнина не превышал 30\%, для хвойного - 60\%. При замене кислорода на азот они выше. Следовательно, не осаждалось из раствора соответственно 70 и 40\%. Скорее всего, они представляют собой низкомолекулярные продукты окисления, однако их структура не изучалась.

Как показали аналитические характеристики продуктов окисления, в ходе электролиза происходят увеличение молекулярной массы, снижение содержания фенольных гидроксильных и увеличение содержания карбоксильных функциональных групп лигнина на фоне снижения выхода продуктов. Таким образом, процесс электрохимического окисления лигнина в этих условиях протекает по двум направлениям: деструкции до низкомолекулярных соединений и полимеризации.

Если полимеризацию можно объяснить в свете обсуждавшихся выше результатов окисления фенольных модельных соединений, особенно если учесть, что содержание фенольных гидроксилов составляет в хвойном сульфатном лигнине около 70/100 ФПЕ [53], то образование большого количества невысаживающися продуктов может быть связано с более высоким содержанием в них карбоксильных групп.

Подобные результаты получены при изучении электрохимического окисления лигнина, содержащегося в черных щелоках органосолвентной варки древесины ели [100]. Разбавленный щелок (рН 13) окисляли на платиновом электроде в термостатируемой ячейке $\left(50{ }^{\circ} \mathrm{C}\right)$ при различных значениях плотности тока (21-200 мА/см²), останавливая процесс при рН 4,5. Лигнин высаживали разбавленной $\mathrm{HCl}$ при рН 2.

Здесь также отчетливо прослеживается отмеченная в работе [99] взаимосвязь снижения содержания фенольных гидроксилов с одновременным увеличением молекулярной массы лигнина. Растет также содержание окисленных групп (карбонильных и карбоксильных), но одновременно увеличивается и содержание алифатических гидроксилов. Этот довольно неожиданный результат авторы связывают с возможной последовательностью реакций, включающей в себя декарбоксилирование части карбоксилсодержащих фрагментов (реакция Кольбе), дальнейшее окисление образовавшихся радикалов до катионов и присоединение к ним нуклеофилов.

$$
\mathrm{R}-\mathrm{CO}_{2}^{-} \rightleftharpoons \mathrm{R}-\mathrm{CO}_{2}^{-}{ }_{(\mathrm{ads})} \stackrel{-\mathrm{e}}{\rightleftharpoons} \mathrm{R}-\mathrm{CO}_{2(\mathrm{ads})} \longrightarrow \mathrm{R}+\mathrm{CO}_{2} \uparrow
$$

$\mathrm{nR} \longrightarrow$ продукты радикальной полимеризации, диспропорционирование, элиминирование

$$
\dot{\mathrm{R}} \stackrel{-\mathrm{e}}{\longrightarrow} \mathrm{R}^{+} \stackrel{\mathrm{Nu}\left(\mathrm{OH}^{-}, \mathrm{H}_{2} \mathrm{O}, \mathrm{ROH}\right)}{\longrightarrow} \text { спирты, простые и сложные эфиры }
$$

На основании данных ЯМР-спектроскопии предполагается расщепление части ароматических колец. Отмечается влияние плотности тока на результаты электролиза.

Изучению растворимой части продуктов электрохимического окисления лигнина с использованием высокоэффективной жидкостной хроматографии посвящены работы [101-103]. Как показало сравнительное исследование материала анода (платина, свинец) и состава раствора (1 M NaOH, 0,5 M $\mathrm{H}_{2} \mathrm{SO}_{4}, 0,5 \mathrm{M}$ $\left.\mathrm{H}_{2} \mathrm{SO}_{4} / \mathrm{CH}_{3} \mathrm{OH}\right)$, предпочтительнее использовать свинцовый анод (2,5×4,0 см) в растворе щелочи.

Окисляли 0,1 г лигнина (лиственного, хвойного или травянистых растений, выделенного из сульфитных и сульфатных щелоков, а также мягковыделенные препараты) в 50 мл анолита в гальваностатическом режиме, при плотности тока 0,5-5,0 A/дм ${ }^{2}$ и температуре $50{ }^{\circ} \mathrm{C}$. В растворимых продуктах электролиза идентифицировано 30 мономерных соединений, однако не все они присутствовали в анолите каждого из исследованных образцов лигнина.

В состав идентифицированных соединений входят фенолы (гваякол, пирокатехин), спирты (ванилиновый, вератровый, конифериловый), различные ароматические альдегиды, кетоны и кислоты, а также алифатические соединения (метилэтилкетон, уксусный альдегид, уксусная кислота, ацетон, пропан-1,2,3трикарбоновая и щавелевая кислоты).

На первый взгляд, в процессе электролиза происходит глубокая окислительная деструкция лигнина, однако суммарный выход перечисленных соединений существенно зависит от происхождения образца и условий электролиза. Для лиственного лигнина выход составляет от 1,09 до 12,05\%, для хвойного 0,02- 
47,78\%, для лигнина травянистых растений - 0,15-67,36\%. Кроме того, в щелочной среде не исключена возможность окисления кислот в виде карбоксилатов по реакции Кольбе с выделением $\mathrm{CO}_{2}$ (см. выше), что не может не сказаться на общем выходе продуктов.

В условиях окисления, использованных в работе [104] (1 М NaOH, при потенциале 0,8 В отн. НКЭ), основными растворимыми продуктами электролиза хвойного сульфатного лигнина являются производные бензальдегида.

Выход нерастворимых продуктов электрохимического окисления лигнина в цитированных статьях [100, 104] не приводится. Тем не менее из сопоставления результатов работ [99] и [101-103] следует, что выход низкомолекулярных продуктов электролиза, растворимых в щелочи, составляет для исследованных технических лигнинов 50\%.

Имеется еще один неожиданный факт, а именно стабильность образовавшихся фенолов и их производных при окислении в щелочной среде, таких лабильных, как пирокатехин и особенно конифериловый спирт. По нашему мнению, это объясняется снижением рН в ходе электролиза за счет взаимодействия фенолов и кислот со щелочью, а также с образовавшимся по реакции Кольбе $\mathrm{CO}_{2}$. Как уже отмечалось, в конце электролиза рН составляет 4,5 [100], а перечисленные соединения в нейтральной форме окисляются значительно труднее, чем соответствующие анионы. Например, $\mathrm{E}_{1 / 2}$ гваякола при рН 13 составляет 0,2 В, а при рН 2 он равен 0,8 В [71].

Образование диоксида углерода в ходе электролиза активированного щелочью гидролизного лигнина отмечается и в работе [105], посвященной изучению влияния материала анода на результаты окисления (табл. 19). При окислении лигнина $\left(50 \Gamma^{-1}{ }^{-1}\right)$ на всех электродах образуется $\mathrm{CO}_{2}$, его выход увеличивается при переходе от платинового и никелевого электродов к графитовому или медному. Судя по результатам анализа, анод из платины позволяет получать менее деструктированные продукты окисления.

На платиновом электроде изучалось влияние потенциала на окисление сульфатного лигнина в растворе $\mathrm{KCl}$ [106]. Установлено, что окисление лигнина при значениях потенциалов поляризации примерно до 0,625 В сопровождается процессами полимеризации, а при более высоких значениях (> 0,750 В) наступает окислительная деструкция лигнина.

Предпринимаются попытки использования электрохимического окисления лигнина для получения ванилина [107-109]. При химическом окислении лигносульфонатов древесины хвойных пород в лабораторных условиях выход ванилина может достигать 30\%, в промышленных - до 10\% [89]. В цитированных работах он значительно меньше.

Способность лигнина к окислению на электроде применяли для его хлорирования [110], бромирования [111], фторирования [112] и нитрования [113]. Механизмы протекающих при этом реакций в цитированных статьях подробно не рассматривались, но не исключено, что реакции галогенирования лигнина протекают по схемам, предложенным для фторирования ароматических соединений [36].

$$
\begin{gathered}
\mathrm{RH} \stackrel{-\mathrm{e}}{\longrightarrow}(\mathrm{RH})^{+} \stackrel{\mathrm{F}^{-}}{\longrightarrow}(\mathrm{RHF}) \stackrel{-\mathrm{e}}{\longrightarrow}(\mathrm{RHF})^{+} \stackrel{-\mathrm{H}^{+}}{\longrightarrow} \mathrm{RF} \\
\mathrm{RH} \stackrel{-2 \mathrm{e},-\mathrm{H}^{+}}{\longrightarrow} \mathrm{R}^{+} \stackrel{\mathrm{F}^{-}}{\longrightarrow} \mathrm{RF}
\end{gathered}
$$

Таблица 19. Выход низкомолекулярных продуктов деструкции и изменение функционального состава лигнина при электрохимическом окислении в щелочной среде [105]

\begin{tabular}{c|c|c|c|c|c|c}
\hline $\begin{array}{c}\text { Материал } \\
\text { анода }\end{array}$ & $\begin{array}{c}\mathrm{COOH,} \\
\text { мг-экв/г }\end{array}$ & $\begin{array}{c}\mathrm{OH}_{\text {фен }}, \\
\text { мг-экв/ }\end{array}$ & $\begin{array}{c}\text { Ванилин, } \\
\%\end{array}$ & $\begin{array}{c}\text { Ванилиновая } \\
\text { кислота, \% }\end{array}$ & $\begin{array}{c}\mathrm{CO}_{2}, \\
\%\end{array}$ & $\begin{array}{c}\text { Алифатические } \\
\text { кислоты, \% }\end{array}$ \\
\hline Платина & 3,30 & 3,48 & 2,0 & 1,5 & 7,6 & $4-5$ \\
Никель & 2,48 & 3,21 & 2,2 & 1,0 & 6,8 & $3-4$ \\
Графит & 2,03 & 4,75 & 0,2 & 0,1 & 11,3 & $5-6$ \\
Медь & 1,72 & 5,30 & 0,2 & 0,1 & 12,8 & $6-8$ \\
\hline
\end{tabular}


При хлорировании и последующих реакциях остаточного лигнина в небеленых целлюлозах в условиях электрохимической отбелки происходят окисление, электрофильное замещение, расщепление ароматических колец и в целом глубокая деструкция лигнина до низкомолекулярных соединений. Подробно эти реакции описаны в работах $[114,115]$ и монографии [116].

Продолжается поиск медиаторов для непрямого электрохимического окисления лигнина, играющих ту же роль, что и ферроцианид калия (уравнения 22, 23) [117-119].

\section{Заключение}

Способность лигнина проявлять диффузионные волны при восстановлении или окислении на различных электродах является скорее исключением из правил. Вследствие высокой молекулярной массы (MМ) полимеры обычно предварительно подвергают гидролизу или пиролизу до мономеров или других низкомолекулярных соединений (при этом индивидуальные особенности полимера, естественно, утрачиваются) либо изучают их свойства по подавлению полярографических максимумов или по способности образовывать каталитические волны водорода в присутствии некоторых веществ [120].

Отмеченное обстоятельство ставит вопрос о ММ лигнина. Она зависит от породы древесины, из которой выделен препарат, метода выделения препарата и метода определения ММ [2, 89]. Относительно недавно методом масс-спектрометрии с «мягкой» ионизацией молекул получены кривые молекулярномассового распределения лигнина, отражающие абсолютные значения ММ [121].

Среднечисленная ММ хвойного лигнина составила $2300 \pm 100$, При типичной для лигнина степени полидисперсности 3,0-3,5 [89] среднемассовая ММ составит 6900-8050. В соответствии с существующей классификацией [122] лигнин, строго говоря, является не полимером, а олигомером, и дело не столько в терминологии, сколько в различии свойств полимеров и олигомеров. Специалистам хорошо известно, что растворы лигнина имеют низкую вязкость, а растворы полимеров, например целлюлозы, - высокую. В упоминавшейся в начале обзора работе [5] методом масс-спектрометрии доказано существование в лигнине линейных гексамеров.

Обобщая опубликованные результаты изучения электрохимических реакций лигнина, можно выявить индивидуальные особенности этого полифункционального соединения в реакциях восстановления и окисления.

При восстановлении на РКЭ реакционными центрами лигнина являются карбонильные группы различных типов и сопряженные двойные связи. Наиболее представительные в лигнине связи $\beta$-О-4 способны к электрохимическому расщеплению при наличии в смежном положении карбонильной группы. В неводных апротонных средах на реакции восстановления лигнина существенное влияние оказывает автопротонирование за счет имеющихся в нем фенольных гидроксильных групп. Непрямое электрохимическое препаративное восстановление, например амальгамами, позволяет проводить деструкцию лигнина до низкомолекулярных соединений. Использование полярографии применительно к лигнину открывает новые возможности анализа функционального состава, а также изучения механизмов химических и электрохимических реакций.

При анодном окислении реакционными центрами лигнина являются ароматические кольца. Наличие в молекуле деполяризатора фенольных гидроксилов облегчает окисление в щелочных средах, однако оно сопровождается реакциями димеризации и полимеризации. В целом процесс окисления развивается по двум направлениям: деструкции до низкомолекулярных соединений, включая $\mathrm{CO}_{2}$, и полимеризации. Максимальная степень деструкции для исследованных препаратов лигнина составляет 50\%.

Лигнин нерастворим в ацетонитриле и кислотах, но, судя по результатам исследования модельных соединений, при окислении в указанных средах можно ожидать глубокой деструкции до ароматических альдегидов, кетонов и кислот, а также алифатических соединений. В водных растворах кислот растворяются производные лигнина - лигносульфонаты, но за исключением пионерской работы [67], в доступной нам литературе мы не обнаружили публикаций, посвященных их электрохимическому окислению именно в кислой среде. В щелочной и нейтральной средах они окисляются подобно другим препаратам лигнина, т.е. в основном полимеризуются [108, 123]. Определенный интерес в качестве среды для электрохимического окисления лигнина представляют ионные жидкости, однако исследования в этой области только начинаются [124, 125]. 


\section{Список литературы}

1. Евстигнеев Э.И. Путь волокна. Значение структуры древесины в технологии волокнистых полуфабрикатов и бумаги. СПб., 2012. 308 с.

2. Лигнины. Структура, свойства и реакции / под ред. К.В. Сарканена, К.Х. Людвига: пер. с англ. М., 1975. 632 с.

3. Шорыгина Н.Н., Резников В.М., Ёлкин В.В. Реакционная способность лигнина. М., 1976. 368 с.

4. Gellerstedt G., Henriksson G. Lignins: major sources, structure and properties // Monomers, Polymers and Composites from Renewable Resources / M. N. Belgacem, A. Gandini (eds.). Amsterdam: Elsevier, 2008. Pp. 201-224.

5. Evtuguin D.V., Amado F.M.L. Application of electrospray ionization mass spectrometry to the elucidation of the primary structure of lignin // Macromol. Biosci. 2003. Vol. 3. Pp. 339-343.

6. Страдынь Я.П. Развитие полярографии органических соединений // Полярография. Проблемы и перспективы Под ред. Я.П. Страдыня и С.Г. Майрановского. Рига, 1972. С. 7-33.

7. Kanda T., Kawakami H. Polarography of thiolignin. 1.The catalytic wave in the cobalt buffer solution // J. Japan Wood Res. Soc. 1956. Vol. 2. Pp. 124-129.

8. Kanda T., Terashima N., Kawakami H. Polarography of lignin. X. On the active group of thiolignin catalytic wave // J. Japan Wood Res. Soc. 1961. Vol. 7, N6. Pp. 258-263.

9. Terashima N., Tamao M., Kanda T. Polarography of lignin. XI. Sulfate cooking of model compounds and polarographic properties of the cooking products // J. Japan Wood Res. Soc. 1968. Vol. 14, N4. Pp. 220-226.

10. Майрановский С.Г. Теория каталитических волн водорода в полярографии органических соединений // Успехи химии. 1964. Т. 33, вып. 1. С. 75-107.

11. Майрановский С.Г., Страдынь Я.П., Безуглый В.Д. Полярография в органической химии. Л., 1975. 351 с.

12. Lindberg J.J., Penttinen K., Majani C. Polarographic investigations on formylguaiacol and veratrols // Acta Chem. Scand. 1965. Vol. 19, N8. Pp. 1991-1992.

13. Lindberg J.J., Penttinen K., Sundholm F. Polarographic reduction and chemical structure of lignin // Paperi ja Puu. 1969. Vol. 51, N11. Pp. 823-825, 827-828, 844.

14. Нгуен ван Тхань, Авруцкая И.А., Фиошин М.Я. Полярографическое поведение ароматических кетонов в кислой среде // Электрохимия. 1968. Т. 4, №12. С. 1508-1511.

15. Авруцкая И.А., Белевский С.Ф., Фиошин М.Я. Нгуен ван Тхань. Полярографическое поведение некоторых алкиларилкетонов в нейтральной и щелочной средах // Электрохимия. 1970. Т. 6, №5. С. 683-687.

16. Peter F., Polcin J., Rapson W.H. Polarographic investigations on some model compounds related to lignin and groundwood bleaching. Part 1. Aromatic aldehydes // Pulp Paper Mag. Can. 1973. Vol. 74, N7. Pp. 89-96.

17. Polcin J., Peter F., Rapson W.H. Polarographic investigations on some model compounds related to lignin and groundwood bleaching // Trans. Tech. Sect. Can. Pulp Paper Assoc. 1976. Vol. 2, N1. Pp. 7-13.

18. Чупка Э.И., Бронов Л.В., Никитин В.М. Полярографическое исследование модельных соединений структурного звена лигнина при нагревании в щелочных средах // Химия древесины. 1974. №15. С. 57-61.

19. Чупка Э.И., Бронов Л.В., Никитин В.М. Окислительно-восстановительные свойства некоторых модельных соединений лигнина в нейтральных и щелочных средах // Химия древесины. 1974. №15. С. 62-67.

20. Стромская Г.И., Чупка Э.И. Особенности электрохимического восстановления ванилина и $\alpha$-гваяцилпропанона в щелочных средах // Химия древесины. 1978. №1. С. 53-57.

21. Горбунова О.Ф., Богомолов Б.Д. О полярографических волнах лигнина на фоне гидроокиси лития // Известия вузов. Лесной журнал. 1973. №3. С. 114-118.

22. Евстигнеев Э.И., Бронов Л.В., Никитин В.М. Полярографическое изучение лигнина в растворителях различной природы. Полярографирование в водной среде // Известия вузов. Лесной журнал. 1978. №5. С. 114-117.

23. Евстигнеев Э.И., Бронов Л.В., Никитин В.М. Полярографическое изучение лигнина в растворителях различной природы. Полярографирование в смешанном и апротонном растворителях // Известия вузов. Лесной журнал. 1978. №6. С. 95-100.

24. Евстигнеев Э.И. Полярографическое исследование лигнина в водном растворе гидроокиси натрия // Журнал прикладной химии. 1981. Т. 54, вып. 2. С. 377-382.

25. Евстигнеев Э.И., Бронов Л.В., Никитин В.М. Применение полярографического метода в анализе функционального состава лигнина. 1. Исследование модельных соединений // Химия древесины. 1979. №6. С. 71-81.

26. Евстигнеев Э.И., Бронов Л.В., Никитин В.М. Применение полярографического метода в анализе функционального состава лигнина. 2. Изучение природы полярографических волн лигнина // Химия древесины. 1979. №6. C. 82-89.

27. А.c. 914993 (СССР). Способ вольтамперометрического определения лигнина в растворах целлюлознобумажного производства / Э.И. Евстигнеев, В.Г. Крунчак. БИ. 1982. №11.

28. Evstigneyev E., Mayiorova H., Platonov A. Polarographically active structural fragments of lignin. I. Monomeric model compounds // J. Wood Chem. Technol. 1999. Vol. 19, N4. Pp. 379-407.

29. Evstigneyev E., Shevchenko S., Mayiorova H., Platonov A. Polarographically active structural fragments of lignin. II. Dimeric model compounds and lignins // J. Wood Chem. Technol. 2004. Vol. 24, N3. Pp. 263-278.

30. Evstigneyev E. I. Schevchenko S.M., Apushkinsky A.G., Semenov S.G. Electrochemistry of lignin model pquinonemethides // Ligno-Cellulosics. Science, Technology, Development and Use, Ellis Horwood, New York. 1992. Pp. 657-670.

31. Evstigneyev E., Mayiorova H., Platonov A. Polarographically active groups and bonds of lignin // Proc. $8^{\text {th }}$ Int. Symp. on Wood and Pulping Chem. Helsinki, Finland, June 6-9. 1995. Vol. 2. Pp. 89-94. 
32. Evstigneyev E., Mayiorova H., Platonov A. Electrochemistry of lignin model compounds // Proc. $10^{\text {th }}$ Int. Symp. on Wood and Pulping Chem. Yokohama, Japan, June 7-10. 1999. Vol. 2. Pp. 106-111.

33. Evstigneyev E., Mayiorova H., Platonov A. Electrochemistry of dimeric lignin model compounds $/ /$ Proc. $7^{\text {th }}$ European Worksshop on Lignocellulosic and Pulp. August 26-29, Turku. 2002. Pp. 193-196.

34. Евстигнеев Э.И. Реакционная способность лигнина в реакциях электрохимического восстановления // Новые достижения в химии и химической технологии растительного сырья : матер. IV Всероссийской конф., Барнаул, 2009. Кн. 1. С. 80-83.

35. Манн С.К., Барнес К.К. Электрохимические реакции в неводных системах. М., 1974. 480 с.

36. Organic Electrochemistry. M.M. Baizer and H. Lund (eds.). New York and Basel: M. Dekker, Inc. 1983. 986 p.

37. Шевченко С.М., Апушкинский А.Г. Хинонметиды в химии древесины (обзор) // Успехи химии. 1992. Т. 61, вып. 1. С. 195-245.

38. Шевченко С.М., Семенов С.Г., Евстигнеев Э.И., Пранович А.В., Гиндин В.А. Физико-химические свойства, электронное строение и реакционная способность модельных $n$-хинонметидов лигнина // Журнал органической химии. 1987. Т. 3, вып. 9. С. 1891-1901.

39. Шевченко С.М., Семенов С.Г., Апушкинский А.Г., Пранович А.В., Евстигнеев Э.И. Электронное строение и физико-химические свойства 2-метокси-4-/2-/2-метоксифенокси//пропилиден-2,5-циклогексадиен-1-она // Журнал органической химии. 1990. Т. 26, вып. 9. С. 1839-1848.

40. Dimmel D.R., Perry L.F., Palasz P.D., Chum H.L. Electron transfer reactions in pulping systems (II): electrochemistry of anthraquinone / lignin model quinone methides // J. Wood Chem. Technol. 1985. Vol. 5, N1. Pp. 15-36.

41. Krupička J., Koutek B., Musil L., Pavličkova L., Souček M. Half-wave potentials of quinone methides in dimethylformamide: substituent effects // Coll. Czechosl. Chem. Commun. 1981. Vol. 46. Pp. 861-872.

42. Koutek B., Pišova M., Krupička J., Lyčka A., Šnobl D., Souček M. Benzoannelated quinone methides // Coll. Czechosl. Chem. Commun. 1982. Vol. 47. Pp. 1645-1653.

43. Кудинова Л.И., Володькин А.А., Ершов В.В., Прокофьева Т.И. Электрохимическое восстановление метиленхинонов // Изв. АН СССР. Сер. хим. 1978. №7. С. 1503-1508.

44. Никулин В.Н., Каргина Н.М., Каргин Ю.М. Электрохимическое восстановление коричного альдегида и халкона в диметилформамиде // Журнал органической химии. 1974. Т. 44, вып. 11. С. 2520-2523.

45. Petrovich J.P., Baizer M.M., Ort M.R. Electrolytic reductive coupling. XVI. A study of 1,2-diactivated olefins. Part I. Voltammetry // J. Electrochem. Soc. 1969. Vol. 116, N6. Pp. 743-749.

46. Ekman K.H., Lindberg J.J. On the origin of the infra-red bands in the $1720 \mathrm{~cm}^{-1}$ region in lignins // Paperi ja Puu. 1960. Vol. 42. Pp. 21-22.

47. Marton J., Adler E. Reactions of lignin with methanol hydrochloric acid. A discussion of some structural questions // Tappi. 1963. Vol. 46. Pp. 92-96.

48. Gellerstedt G., Lindfors E. Hydrophilic groups in lignin after oxygen bleaching // Tappi J. 1987. Vol. 70, N 6. Pp. 119-122.

49. Lund H. Electroorganic preparation. IX. Polarography and reduction of substituted aryl alkyl ketones // Acta Chem. Scand. 1960. Vol. 14, N9. Pp. 1927-1938.

50. Chum H.L., Ratcliff M., Schroeder H.A., Sopher D.W. Electrochemistry of biomass-derived materials. I. Characterization, fractionation and reductive electrolysis of ethanol-extracted explosively-depressurized aspen lignin // J. Wood Chem. Technol. 1984. Vol. 4, N4. Pp. 505-532.

51. Limosin D., Pierre G., Cauquis G. Étude Électrochimique de quelques Composés Diméres Modéles de la Lignine // Holzforschung. 1985. Vol. 39, N2. Pp. 91-98.

52. Шевченко С.М., Дейнеко И.П. Химия антрахинонной варки (обзор) // Химия древесины. 1983. №6. С. 3-32.

53. Evstigneyev E., Maiyorova H., Platonov A. Lignin functionalization and the alkaline delignification rate // Tappi J. 1992. Vol. 75, N5. Pp. 177-182.

54. Майорова Е.Д., Платонов А.Ю., Евстигнеев Э.И., Чистоклетов В.Н. Кинетика и механизм расщепления модельных 2-ароксиалкилароматических структур лигнина под действием антрагидрохинона в щелочной среде // Журнал органической химии. 1992. Т. 62, вып. 5. С. 1170-1176.

55. Maiyorova H., Platonov A., Evstigneyev E. About significance of nonphenolic lignin structure in alkaline pulping with anthraquinone // Proc. The $8^{\text {th }}$ Int. Symp. on Wood and Pulping Chem. Helsinki. 1995. Vol. 2. Pp. 291-296.

56. Евстигнеев Э.И., Шалимова Т.В. Редокс-свойства, каталитическая активность и стабилизирующий эффект при натронной варке некоторых соединений ряда хинонов. 1. Потенциалы восстановления и растворимость // Химия древесины. 1985. №1. С. 50-54.

57. Евстигнеев Э.И., Шалимова Т.В. Редокс-свойства, каталитическая активность и стабилизирующий эффект при натронной варке некоторых соединений ряда хинонов. 2. Влияние на варку // Химия древесины. 1985. №1. C. 55-60.

58. Shevchenko S.M., Zubarev V.E., Rudenko A.P. On the formation of anthrasemiquinone in the conditions of wood alkaline pulping // Croatica Chem. Acta. 1988. Vol. 61. Pp. 763-773.

59. Евстигнеев Э.И. Антрасемихинон ускоряет делигнификацию // Химия древесины. 1984. №5. С. 97-98.

60. Чупка Э.И., Стромская Г.И., Бронов Л.В. О восстановлении лигнина амальгамами в различных растворителях // Химия древесины. 1976. №6. С. 46-48.

61. Чупка Э.И., Липскис А.А., Никитин В.М. Расщепление лигнина при электрохимическом восстановлении в аммиачных растворах // Химия древесины. 1976. №2. С. 72-74.

62. Стромская Г.И., Чупка Э.И., Стромский С.В. Исследование особенностей восстановления лигнина и модельных соединений амальгамами // Химия древесины. 1977. №1. С. 77-82. 
63. Стромская Г.И., Чупка Э.И. Электрохимическое восстановление лигнина и его модельных соединений в апротонных растворителях // Химия древесины. 1978. №2. С. 65-68.

64. Стромская Г.И., Чупка Э.И. Электрохимическое восстановление лигнина в жидком аммиаке. 1. Изменение хромофорного и молекулярно-массового состава лигнина при электрохимическом восстановлении в жидком аммиаке // Химия древесины. 1983. №2. С. 60-63.

65. Гоготов А.Ф., Чупка Э.И. Электрохимическое восстановление нитропроизводных лигнина // Химия древесины. 1979. №3. С. 53-57.

66. Гоготов А.Ф., Чупка Э.И., Раскин М.Н. Модификация технического нитролигнина методом электрохимического восстановления // Гидролизная и лесохимическая промышленность. 1980. №5. С. 5-7.

67. Гоготов А.Ф., Чупка Э.И. Изменение физико-химических свойств нитролигнина при фотоэлектрохимическом восстановлении // Химия древесины. 1983. №2. С. 64-67.

68. König F. // Cellulosechem. 1921. N2. P. 93.

69. O'Connor J.J. Electrochemical studies of 3,4-dimethoxypropenyl benzene. Voltammetry and controlled potential oxidation at a rotating platinum electrode in acetonitrile : Doctor's dissertation. The Institute of Paper Chemistry Appleton, Wisconsin. 1962.

70. Bailey A. J., Brooks H. M. Electrolytic oxidation of lignin // J. Am. Chem. Soc. 1946. Vol. 68, N3. Pp. $445-446$.

71. Водзинский Ю.В., Васильева А.А., Коршунов И.А. Анодная вольтамперометрия пространственнозатрудненных фенолов // Журнал органической химии. 1969. Т. 39, вып. 5. С. 1196-1202.

72. Корытцева В.Ф., Водзинский Ю.В., Скворцов Н.П. Вольтамперометрическое окисление лигнинов на графитовом электроде. 1. Потенциалы окисления лигнинов // Химия древесины. 1978. №6. С. 79-81.

73. Корытцева В.Ф., Водзинский Ю.В., Скворцов Н.П. Вольтамперометрическое окисление лигнинов на графитовом электроде. 2. Токи электроокисления лигнинов // Химия древесины. 1979. №1. С. 87-90.

74. Корытцева В.Ф., Водзинский Ю.В., Латыпова В.З., Каргин Ю.М. О механизме электроокисления гваякола и лигнина на графитовом электроде // Известия вузов. Лесной журнал. 1980. №2. С. 82-85.

75. Yasukouchi K., Taniguchi I., Yamaguchi H., Amameishi T., Takao M. Anodic oxidation of methoxyphenols. I. Anodic demethoxylation of vanillin // Denki Kagaki. 1979. Vol. 47, N9. Pp. 573-575.

76. Лихушина Л.К., Соколова А.А., Семакова Л.А. Исследование методом анодной вольтамперометрии щелоков от окислительно-щелочного способа делигнификации лиственной древесины и одубины // Химия древесины. 1985. №2. С. 58-62.

77. Физическая химия лигнина / под ред. К.Г. Боголицына, В.В. Лунина. М., 2010. 492 с.

78. Боголицын К.Г., Иванченко Н.Л., Потапова Е.Ф., Шкаев А.Н. Исследование влияния состава растворителя на окисление ванилина и гваякола на платиновом электроде // Химия растительного сырья. 2006. №1. С. 11-14.

79. Медведев В.А., Бабкин В.А., Горохова Л.Т., Анисимова М.И., Медведева С.А., Петрушенко Л.Н. Электрохимия растительных материалов и продуктов их переработки. 4. Кинетика анодного окисления и адсорбция ванилинового спирта на твердых электродах // Химия древесины. 1982. №1. С. 82-86.

80. Медведев В.А., Янилкин В.В., Бабкин В.А., Иванова С.3., Васянович Г.П. Влияние материала электрода на электроокисление гваякола и пирокатехина // Химия древесины. 1985. №4. С. 82-86.

81. Щукин И.В., Казаринов В.Е., Васильев Ю.Б., Бабкин В.А. Адсорбция лигнина и ароматических соединений на платиновом электроде // Электрохимия. 1985. Т. 21. №5. С. 725-732.

82. Hapiot P., Pinson J., Francesch C., Mhamdi F., Rolando C., Neta P. Oxidative dimerization of phenolic aldehydes related to lignin formation // J. Phys. Chem. 1994. Vol. 98, N10. Pp. 2641-2645.

83. Evans H., Jimenez P.J., Kelly M.J. Reversible dimerization of phenoxyl radicals by anodic oxidation of phenolates // J. Electroanal. Chem. 1984. Vol. 163, N1-2. Pp. 145-157.

84. Iguci M., Nishiyama A., Eto H., Yamamura S. Anodic oxidation of propenylphenols // Chem. Lett. 1981. N7. Pp. 939-942.

85. Ogawa H. Oxidation potential of lignin model compounds // Kagaku Gijutsu Kenkyusho Hokoku. 1985. Vol. 80, N2. Pp. 31-36.

86. Ohmori H., Ueda C., Tokuno Y., Maeda H., Masui M. Electrochemical oxidation of 2,6-ditertbutyl-4-methylphenol in basic methanol // Chem. and Pharm. Bull. 1985. Vol. 33, N9. Pp. 4007-4011.

87. Kishioka S-Y., Ymada A. Electrooxidation of vanillyl alcohol in acidic aqueous solution using rotating ring-disk electrode voltammetry // Analytical Sciences. 2005. Vol. 21, N4. Pp. 429-432.

88. Fichter F., Christen A. Über die elektrochemische Oxydation von Anethol und Isoeugenol // Helv. Chim. Acta. 1925. Vol. 8, issue 1. Pp. 332-336.

89. Фенгел Д., Вегенер Г. Древесина. Химия, ультраструктура, реакции. Пер. с англ. М., 1988. 512 с.

90. Fichter F., Dietrich W. Elektrochemische Oxydation von Alkyläthern des Phenols und der drei isomeren Dioxybenzole // Helv. Chim. Acta. 1924. Vol. 7, issue 1. Pp. 131-143.

91. Musgrave O.C. The oxidation of alkyl aryl ethers // Chem. Revs., 1969. Vol. 69, N4. Pp. 449-531.

92. Mann C.K. Nonaqueous solvents for electroanalytical use // Electroanal. Chem. 1969. Vol. 3. Pp. 57-134.

93. Sundholm F., Sundholm G. Anodic oxidation of cathecol // Finn. Chem. Lett. 1981. N7-8. Pp. 85-86.

94. Sundholm F. Anodic oxidation as tool for mechanistic studies // Holzforschung. 1982. Bd. 36. H. 2. S. 71-75.

95. Янилкин В.В., Медведев В.А., Бабкин В.А., Иванова С.З., Медведева С.А. Механизм электрохимического окисления 2-метоксифенолов // Изв. СО АН СССР, сер. хим. наук. 1985. №17/6. С. 132-135.

96. Shiraishi T., Takano T., Kamitakahara H., Nakatsubo F. Studies on electrooxidation of lignin and lignin model compounds. Part 1: Direct electrooxidation of non-phenolic lignin model compounds // Holzforschung. 2011. Vol. 66, issue 3. Pp. 303-309. 
97. Shiraishi T., Takano T., Kamitakahara H., Nakatsubo F. Studies on electrooxidation of lignin and lignin model compounds. Part 2: $\mathrm{N}$-Hydroxyphthalimide (NHPI)-mediated indirect electro-oxidation of non-phenolic lignin model compounds // Holzforschung. 2011. Vol. 66. Issue 3. Pp. 311-315.

98. Дуденко Л.Ю., Анисимова М.И., Янилкин В.В., Бабкин В.А., Иванова С.З., Спиридонова Л.Н., Горохова В.Г. Анодное окисление $\beta$-гваяцилового эфира вератрилпропанона-1 // Химия древесины. 1985. №5. С. 70-75.

99. Limosin D., Pierre G., Cauquis G. Oxydation Électrochimique de quelques Echantillons de Lignine en Solution Aqueuse Basique // Holzforschung. 1986. Vol. 40, issue 1. Pp. 31-36.

100. Löbbecke J.G., Lindner A., Wegener G., Wabner D.W. Anodic modification of lignins during electrolysis in the Organocell process // Holzforschung. 1990. Vol. 44, issue 6. Pp. 401-406.

101. Yoshiama A., Nonaka T., Chou T-C., Tien H-J. Anodic degradation of lignins I. Hardwood lignins // J. Jap. Wood Res. Soc. 1988. Vol. 34, N2. Pp. 155-161.

102. Yoshiama A., Nonaka T., Kawakami H., Chou T-C., Tien H-J. Anodic degradation of lignins II. Softwood lignins // J. Jap. Wood Res. Soc. 1988. Vol. 34, N3. Pp. 2755-280.

103. Yoshiama A., Chou T-C., Nonaka T., Kawakami H., Tien H-J. Anodic degradation of lignins III. Herbal lignins // J. Jap. Wood Res. Soc. 1988. Vol. 34, N8. Pp. 702-706.

104. Lalvani S.B., Rajagopal P. Hydrogen production from lignin-water solution by electrolysis // Holzforschung. 1993. Vol. 47, issue 4. Pp. 283-286.

105. Коваленко Е.И., Смирнов В.А., Шалимов В.Н. Влияние материала анода и времени электролиза на направленность электрохимического окисления гидролизного лигнина // Журнал прикладной химии. 1977. Т. 50, вып. 8. С. 1741-1744.

106. Анисимова М.И., Бабкин В.А., Кожевникова Л.Г., Зайцева Л.А., Васянович Г.П., Исакова Н.В. Электрохимия растительных материалов и продуктов их переработки. 3. Анодное окисление сульфатного лигнина при потенциалах до выделения кислорода // Химия древесины. 1980. №2. С. 72-77.

107. Parpot P., Bettencourt A.P., Carvalho A.M., Belgsir E.M. Biomass conversion: attempted electrooxidation of lignin for vanillin production // J. Appl. Electrochem. 2000. Vol. 30. Pp. 727--731.

108. Moodley B., Mulholland D.A., Brookes H.C. The electro-oxidation of lignin in Sappi Saiccor dissolving pulp mill effluent // Water SA. 2011. Vol. 37, N1. Pp. 33-40.

109. Smith C., Utley J.H.P. Biomass electrochemistry: anodic oxidation of an organo-solv lignin in the presence of nitroaromatics // J. Appl. Electrochem. 1989. Vol. 19. Pp. 535-539.

110. Коваленко Е.И., Котенко Н.П., Смирнов В.А., Ляшко О.В. Электрохимическое хлорирование лигнина в неводных апротонных средах // Химия древесины. 1986. №5. С. 66-72.

111. Коваленко Е.И., Котенко Н.П., Смирнов В.А., Саратова Л.А. Электрохимическое бромирование лигнина в неводных апротонных средах // Химия древесины. 1986. №6. С. 98-101.

112. Попова О.В. Научные основы электрохимического модифицирования лигнинов: автореф. дис... докт. тех. наук. Саратов, 2006. $41 \mathrm{c}$.

113. Коваленко Е.И., Котенко Н.П. Электрохимическое нитрование лигнина // Журнал прикладной химии. 1990. Т. 63, №2. С. 389-395.

114. Демин В.А., Давыдов В.Д., Богомолов Б.Д. Исследование электрохимического окисления лигнина // Химия древесины. 1979. №2. С. 41-44.

115. Демин В.А., Богомолов Б.Д., Карманов А.П., Давыдов В.Д. Структурные изменения сульфатного лигнина в процессе электрохимического окисления // Химия древесины. 1980. №4. С. 82-84.

116. Демин В.А., Давыдов В.Д., Богомолов Б.Д. Электрохимическая отбелка сульфатной целлюлозы. Л., 1982. 135 с.

117. Padtberg C., Kim H.-C., Mickel M., Bartling S., Hampp N. Electrochemical delignification of softwood pulp with violuric acid // Tappi J. 2001. Vol. 84, N4. Pp. 68-69.

118. Hampp N., Bartling S., Kim H.-C., Mickel M. Electrochemically mediated bleaching of pulp fibers // Electrochimica Acta. 2001. Vol. 47, issue 5. Pp. 799-805.

119. Mickel M., Kim H.-C., Hampp N. Origin of the mediator losses in electrochemical delignification processes: Primary and secondary reactions of violuric acid and $\mathrm{N}, \mathrm{N}$ '-dimethylvioluric acid radicals with lignin model compound // Green Chem. 2003. Vol. 5. Рp. 8-14.

120. Безуглый В.Д. Полярография в химии и технологии полимеров. Л., 1968. 232 с.

121. Metzger J.O., Bicke O., Faix O., Tuszynski W., Angermann R., Karas M., Strupat K. Matrix-assisted laser desorption mass spectrometry of lignins // Angew. Chem. Int. Ed. Engl. 1992. Vol. 31, N6. Pp. 762-764.

122. Энтелис С.Г., Евреинов В.В., Кузаев А.И. Реакционноспособные олигомеры. М., 1985. 304 с.

123. Vagin M.Yu., Trashin S.A., Karyakin A.A. Corrosion protection of steel by electropolymerized lignins // Electrochem. Commun. 2006. Vol. 8, issue 1. Pp. 60-64.

124. Chen A., Rogers E.I., Compton R.G. Abrasive stripping voltammetric studies of lignin and lignin model compounds // Electroanalysis. 2010. Vol. 22, issue 10. Pp. 1037-1044.

125. Reichert E., Wintringer R., Volmer D.A., Hempelmann R. Electro-catalytic oxidative cleavage of lignin in a protic ionic liquid // Phys. Chem. Chem. Phys. 2012. Vol. 14. Pp. 5214-5221.

Поступило в редакцию 1 октября 2013 г. После переработки 26 июня 2014 г. 
Evstigneev E.I. ELECTROCHEMICAL REACTIONS OF LIGNIN

St. Petersburg State Forestry University, Institutskii st., 5, St. Petersburg, 124021 (Russia), e-mail:edward_evst@mail.ru

The review deals with the reactivity and mechanisms of electrochemical reactions of lignin model compounds and the reduction and oxidation in various electrodes in aqueous, aqueous-organic and non-aqueous media. Reactions direct and indirect cathode and anode are discussed, as well as in non-aqueous media autoprotonation and electrocatalytic reactions. The reaction center in the reduction of lignin in the dropping mercury electrode are different types of carbonyl groups and conjugated double bonds. Bonds b-O-4, the most representative in the lignin capable electrochemical cleavage in the presence of the carbonyl group adjacent position. Autoprotonation from existing in lignin phenolic hydroxyl groups in non-aqueous aprotic media for the reduction reaction has a significant impact. Preparative recovery of indirect electrochemical, such as amalgam, allows for the destruction of lignin to low molecular weight compounds. Use of polarography in relation to lignin opens up new possibilities of functional analysis, as well as studying the mechanisms of chemical and electrochemical reactions. Reaction centers are lignin aromatic ring at anodic oxidation. The presence in the molecule of phenolic hydroxyl depolarizer facilitates oxidation in alkaline media, but it is accompanied by the dimerization and polymerization reactions. In general, the oxidation process is developed in two directions: to the degradation of low molecular weight compounds, including $\mathrm{CO} 2$, and polymerization. The maximum degree of degradation of the investigated drugs lignin is $~ 50 \%$. Lignin is insoluble in acetonitrile and acids, but according to a study model compounds by oxidation in these media can be expected to deep destruction of aromatic aldehydes, ketones and acids, and aliphatic compounds.

Keywords: lignin, model compounds, polarography, voltammetry, preparative electrolysis, electrochemical reactions, autoprotonation, electrocatalytic reactions.

\section{References}

1. Evstigneev E.I. Put' volokna. Znachenie struktury drevesiny v tekhnologii voloknistykh polufabrikatov i bumagi. [The path of the fiber. The value of timber frame technology fiber intermediates and paper]. St. Petersburg, 2012, 308 p. (in Russ.).

2. Ligniny. Struktura, svoistva i reaktsii. [Lignins. The structure, properties and reactions]. Ed. K.V. Sarkanen, K.Kh. Liudvig. Moscow, 1975, 632 p. (in Russ.).

3. Shorygina N.N., Reznikov V.M., Elkin V.V. Reaktsionnaia sposobnost' lignina. [Reactivity of lignin]. Moscow, 1976, 368 p. (in Russ.).

4. Gellerstedt G., Henriksson G. Monomers, Polymers and Composites from Renewable Resources. Ed. M.N. Belgacem, A. Gandini. Amsterdam, 2008, pp. 201-224.

5. Evtuguin D.V., Amado F.M.L. Macromol. Biosci., 2003, vol. 3, pp. 339-343.

6. Stradyn' Ia.P. Poliarografiia. Problemy i perspektivy. [Polarography. Problems and prospects]. Ed. Ia.P. Stradynia, S.G. Mairanovskii. Riga, 1972, pp. 7-33. (in Russ.).

7. Kanda T., Kawakami H. J. Japan Wood Res. Soc., 1956, vol. 2, pp. 124-129.

8. Kanda T., Terashima N., Kawakami H. J. Japan Wood Res. Soc., 1961, vol. 7, N6, pp. 258-263.

9. Terashima N., Tamao M., Kanda T. J. Japan Wood Res. Soc., 1968, vol. 14, N4, pp. 220-226.

10. Mairanovskii S.G. Uspekhi khimii, 1964, vol. 33, no. 1, pp. 75-107. (in Russ.).

11. Mairanovskii S.G., Stradyn' Ia.P., Bezuglyi V.D. Poliarografiia v organicheskoi khimii. [Polarography in organic chemistry]. Leningrad, 1975, 351 p. (in Russ.).

12. Lindberg J.J., Penttinen K., Majani C. Acta Chem. Scand., 1965, vol. 19, no. 8, pp. 1991-1992.

13. Lindberg J.J., Penttinen K., Sundholm F. Paperi ja Puu., 1969, vol. 51, no. 11, pp. 823-825, 827-828, 844.

14. Nguen van Tkhan', Avrutskaia I.A., Fioshin M.Ia. Elektrokhimiia, 1968. T. 4, №12. C. 1508-1511. (in Russ.).

15. Avrutskaia I.A., Belevskii S.F., Fioshin M.Ia. Nguen van Tkhan'. Elektrokhimiia, 1970, vol. 6, no. 5, pp. 683-687. (in Russ.).

16. Peter F., Polcin J., Rapson W.H. Pulp Paper Mag. Can., 1973, vol. 74, no. 7, pp. 89-96.

17. Polcin J., Peter F., Rapson W.H. Trans. Tech. Sect. Can. Pulp Paper Assoc., 1976, vol. 2, no. 1, pp. 7-13.

18. Chupka E.I., Bronov L.V., Nikitin V.M. Khimiia drevesiny, 1974, no. 15, pp. 57-61. (in Russ.).

19. Chupka E.I., Bronov L.V., Nikitin V.M. Khimiia drevesiny, 1974, no. 15, pp. 62-67. (in Russ.).

20. Stromskaia G.I., Chupka E.I. Khimiia drevesiny, 1978, no. 1, pp. 53-57. (in Russ.).

21. Gorbunova O.F., Bogomolov B.D. Izvestiia vuzov. Lesnoi zhurnal, 1973, no. 3, pp. 114-118. (in Russ.).

22. Evstigneev E.I., Bronov L.V., Nikitin V.M. Izvestiia vuzov. Lesnoi zhurnal, 1978, no. 5, pp. 114-117. (in Russ.)

23. Evstigneev E.I., Bronov L.V., Nikitin V.M. Izvestiia vuzov. Lesnoi zhurnal, 1978, no. 6, pp. 95-100. (in Russ.).

24. Evstigneev E.I. Zhurnal prikladnoi khimii, 1981, vol. 54, no. 2, pp. 377-382. (in Russ.).

25. Evstigneev E.I., Bronov L.V., Nikitin V.M. Khimiia drevesiny, 1979, no. 6, pp. 71-81. (in Russ.).

26. Evstigneev E.I., Bronov L.V., Nikitin V.M. Khimiia drevesiny, 1979, no. 6, pp. 82-89. (in Russ.).

27. Patent 914993 (USSR). 1982. (in Russ.).

28. Evstigneyev E., Mayiorova H., Platonov A. J. Wood Chem. Technol., 1999, vol. 19, no. 4, pp. 379-407.

29. Evstigneyev E., Shevchenko S., Mayiorova H., Platonov A. J. Wood Chem. Technol., 2004, vol. 24, no. 3, pp. $263-278$.

30. Evstigneyev E. I. Schevchenko S.M., Apushkinsky A.G., Semenov S.G. Ligno-Cellulosics. Science, Technology, Development and Use. Ellis Horwood, New York, 1992, pp. 657-670. 
31. Evstigneyev E., Mayiorova H., Platonov A. Proc. 8th Int. Symp. on Wood and Pulping Chem. Helsinki, Finland. 1995, vol. 2, pp. 89-94.

32. Evstigneyev E., Mayiorova H., Platonov A. Proc. 10th Int. Symp. on Wood and Pulping Chem. Yokohama, Japan, 1999, vol. 2, pp. 106-111.

33. Evstigneyev E., Mayiorova H., Platonov A. Proc. 7th European Worksshop on Lignocellulosic and Pulp, Turku, 2002, pp. 193-196.

34. Evstigneev E.I. Novye dostizheniia v khimii i khimicheskoi tekhnologii rastitel'nogo syr'ia: materialy IV Vserossiiskoi konf., [New advances in chemistry and chemical technology of vegetable raw materials: materials of the IV All-Russian Conference]. Barnaul, 2009, book. 1, pp. 80-83. (in Russ.).

35. Mann S.K., Barnes K.K. Elektrokhimicheskie reaktsii $\mathrm{v}$ nevodnykh sistemakh. [Electrochemical reactions in nonaqueous systems]. Moscow, 1974, 480 p. (in Russ.).

36. Organic Electrochemistry. M.M. Baizer and H. Lund (eds.). New York and Basel: M. Dekker, Inc. 1983. 986 p.

37. Shevchenko C.M., Apushkinskii A.G. Uspekhi khimii, 1992, vol. 61, no. 1, pp. 195-245. (in Russ.).

38. Shevchenko S.M., Semenov S.G., Evstigneev E.I., Pranovich A.V., Gindin V.A. Zhurnal organicheskoi khimii, 1987, vol. 3, no. 9, pp. 1891-1901. (in Russ.).

39. Shevchenko S.M., Semenov S.G., Apushkinskii A.G., Pranovich A.V., Evstigneev E.I. Zhurnal organicheskoi khimii, 1990, vol. 26, no. 9, pp. 1839-1848. (in Russ.).

40. Dimmel D.R., Perry L.F., Palasz P.D., Chum H.L. J. Wood Chem. Technol., 1985, vol. 5, no. 1, pp. 15-36.

41. Krupička J., Koutek B., Musil L., Pavličkova L., Souček M. Coll. Czechosl. Chem. Commun., 1981, vol. 46, pp. 861-872.

42. Koutek B., Pišova M., Krupička J., Lyčka A., Šnobl D., Souček M. Coll. Czechosl. Chem. Commun., 1982, vol. 47, pp. $1645-1653$.

43. Kudinova L.I., Volod'kin A.A., Ershov V.V., Prokof'eva T.I. Izvestiia AN SSSR. Seriia khimicheskaia, 1978, no. 7, pp. 1503-1508. (in Russ.).

44. Nikulin V.N., Kargina N.M., Kargin Iu.M. Zhurnal organicheskoi khimii, 1974, vol. 44, no. 11, pp. 2520-2523. (in Russ.).

45. Petrovich J.P., Baizer M.M., Ort M.R. J. Electrochem. Soc., 1969, vol. 116, no. 6, pp. 743-749.

46. Ekman K.H., Lindberg J.J. Paperi ja Puu., 1960, vol. 42, pp. 21-22.

47. Marton J., Adler E. Tappi, 1963, vol. 46, pp. 92-96.

48. Gellerstedt G., Lindfors E. Tappi J., 1987, vol. 70, no. 6, pp. 119-122.

49. Lund H. Acta Chem. Scand., 1960, vol. 14, no. 9, pp. 1927-1938.

50. Chum H.L., Ratcliff M., Schroeder H.A., Sopher D.W. J. Wood Chem. Technol., 1984, vol. 4, no. 4, pp. $505-532$.

51. Limosin D., Pierre G., Cauquis G. Holzforschung, 1985, vol. 39, no. 2, pp. 91-98.

52. Shevchenko S.M., Deineko I.P. Khimiia drevesiny, 1983, no. 6, pp. 3-32. (in Russ.).

53. Evstigneyev E., Maiyorova H., Platonov A. Tappi J., 1992, vol. 75, no. 5, pp. 177-182.

54. Maiorova E.D., Platonov A.Iu., Evstigneev E.I., Chistokletov V.N. Zhurnal organicheskoi khimii, 1992, vol. 62, no. 5, pp. 1170-1176. (in Russ.).

55. Maiyorova H., Platonov A., Evstigneyev E. Proc. The 8th Int. Symp. on Wood and Pulping Chem. Helsinki, 1995, vol. 2, pp. 291-296.

56. Evstigneev E.I., Shalimova T.V. Khimiia drevesiny, 1985, no. 1, pp. 50-54. (in Russ.).

57. Evstigneev E.I., Shalimova T.V. Khimiia drevesiny, 1985, no. 1, pp. 55-60. (in Russ.).

58. Shevchenko S.M., Zubarev V.E., Rudenko A.P. Croatica Chem. Acta, 1988, vol. 61, pp. 763-773.

59. Evstigneev E.I. Khimiia drevesiny. 1984. №5. S. 97-98. (in Russ.).

60. Chupka E.I., Stromskaia G.I., Bronov L.V. Khimiia drevesiny, 1976, no. 6, pp. 46-48. (in Russ.).

61. Chupka E.I., Lipskis A.A., Nikitin V.M. Khimiia drevesiny, 1976, no. 2, pp. 72-74. (in Russ.).

62. Stromskaia G.I., Chupka E.I., Stromskii S.V. Khimiia drevesiny, 1977, no. 1, pp. 77-82. (in Russ.).

63. Stromskaia G.I., Chupka E.I. Khimiia drevesiny, 1978, no. 2, pp. 65-68. (in Russ.).

64. Stromskaia G.I., Chupka E.I. Khimiia drevesiny, 1983, no. 2,. pp. 60-63. (in Russ.).

65. Gogotov A.F., Chupka E.I. Khimiia drevesiny, 1979, no. 3, pp. 53-57. (in Russ.).

66. Gogotov A.F., Chupka E.I., Raskin M.N. Gidroliznaia i lesokhimicheskaia promyshlennost', 1980, no. 5, pp. 5-7. (in Russ.).

67. Gogotov A.F., Chupka E.I. Khimiia drevesiny, 1983, no. 2, pp. 64-67. (in Russ.).

68. König F. // Cellulosechem. 1921. N2. P. 93.

69. O'Connor J.J. Electrochemical studies of 3,4-dimethoxypropenyl benzene. Voltammetry and controlled potential oxidation at a rotating platinum electrode in acetonitrile : Doctor's dissertation. The Institute of Paper Chemistry Appleton, Wisconsin. 1962.

70. Bailey A.J., Brooks H.M. J. Am. Chem. Soc., 1946, vol. 68, no. 3, pp. 445-446.

71. Vodzinskii Iu.V., Vasil'eva A.A., Korshunov I.A. Zhurnal organicheskoi khimii, 1969, vol. 39, no. 5, pp. 1196-1202. (in Russ.).

72. Koryttseva V.F., Vodzinskii Iu.V., Skvortsov N.P. Khimiia drevesiny, 1978, no. 6, pp. 79-81. (in Russ.).

73. Koryttseva V.F., Vodzinskii Iu.V., Skvortsov N.P. Khimiia drevesiny, 1979, no. 1, pp. 87-90. (in Russ.). 
74. Koryttseva V.F., Vodzinskii Iu.V., Latypova V.Z., Kargin Iu.M. Izvestiia vuzov. Lesnoi zhurnal, 1980, no. 2, pp. 82-85. (in Russ.).

75. Yasukouchi K., Taniguchi I., Yamaguchi H., Amameishi T., Takao M. Denki Kagaki, 1979, vol. 47, no. 9, pp. $573-575$.

76. Likhushina L.K., Sokolova A.A., Semakova L.A. Khimiia drevesiny, 1985, no. 2, pp. 58-62. (in Russ.).

77. Fizicheskaia khimiia lignina. [Physical chemistry of lignin]. Ed. K.G. Bogolitsyn, V.V. Lunin. Moscow, 2010,492 p. (in Russ.).

78. Bogolitsyn K.G., Ivanchenko N.L., Potapova E.F., Shkaev A.N. Khimiia rastitel'nogo syr'ia, 2006, no. 1. pp. 11-14. (in Russ.).

79. Medvedev V.A., Babkin V.A., Gorokhova L.T., Anisimova M.I., Medvedeva S.A., Petrushenko L.N. Khimiia drevesiny, 1982, no. 1, pp. 82-86. (in Russ.).

80. Medvedev V.A., Ianilkin V.V., Babkin V.A., Ivanova S.Z., Vasianovich G.P. Khimiia drevesiny, 1985, no. 4, pp. 8286. (in Russ.).

81. Shchukin I.V., Kazarinov V.E., Vasil'ev Iu.B., Babkin V.A. Elektrokhimiia, 1985, vol. 21, no. 5, pp. 725-732. (in Russ.).

82. Hapiot P., Pinson J., Francesch C., Mhamdi F., Rolando C., Neta P. J. Phys. Chem., 1994, vol. 98, no. 10, pp. 2641-2645.

83. Evans H., Jimenez P.J., Kelly M.J. J. Electroanal. Chem., 1984, vol. 163, no. 1-2, pp. 145-157.

84. Iguci M., Nishiyama A., Eto H., Yamamura S. Chem. Lett., 1981, no. 7, pp. 939-942.

85. Ogawa H. Kagaku Gijutsu Kenkyusho Hokoku, 1985, vol. 80, no. 2, pp. 31-36.

86. Ohmori H., Ueda C., Tokuno Y., Maeda H., Masui M. Chem. and Pharm. Bull., 1985, vol. 33, no. 9, pp. 4007-4011.

87. Kishioka S-Y., Ymada A. Analytical Sciences, 2005, vol. 21, no. 4, pp. 429-432.

88. Fichter F., Christen A. Helv. Chim. Acta, 1925, vol. 8, issue 1, pp. 332-336. (in German).

89. Fengel D., Vegener G. Drevesina. Khimiia, ul'trastruktura, reaktsii. [Wood. Chemistry, ultrastructure, reactions]. Moscow, 1988, 512 p. (in Russ.).

90. Fichter F., Dietrich W. Helv. Chim. Acta, 1924, vol. 7, issue 1, pp. 131-143. (in German).

91. Musgrave O.C. Chem. Revs., 1969, vol. 69, N4, pp. 449-531.

92. Mann C.K. Electroanal. Chem., 1969, vol. 3, pp. 57-134.

93. Sundholm F., Sundholm G. Finn. Chem. Lett., 1981, no. 7-8, pp. 85-86.

94. Sundholm F. Holzforschung, 1982. Bd. 36. H. 2. S. 71-75.

95. Ianilkin V.V., Medvedev V.A., Babkin V.A., Ivanova S.Z., Medvedeva S.A. Izvestiia SO AN SSSR. Seriia khimicheskikh nauk, 1985, no. 17/6, pp. 132-135. (in Russ.).

96. Shiraishi T., Takano T., Kamitakahara H., Nakatsubo F. Holzforschung, 2011, vol. 66, issue 3, pp. 303-309.

97. Shiraishi T., Takano T., Kamitakahara H., Nakatsubo F. Holzforschung, 2011, vol. 66. Issue 3, pp. 311-315.

98. Dudenko L.Iu., Anisimova M.I., Ianilkin V.V., Babkin V.A., Ivanova S.Z., Spiridonova L.N., Gorokhova V.G. Khimiia drevesiny, 1985, no. 5, pp. 70-75. (in Russ.).

99. Limosin D., Pierre G., Cauquis G. Holzforschung, 1986, vol. 40, issue 1, pp. 31-36.

100. Löbbecke J.G., Lindner A., Wegener G., Wabner D.W. Holzforschung, 1990, vol. 44, issue 6, pp. 401-406.

101. Yoshiama A., Nonaka T., Chou T-C., Tien H-J. J. Jap. Wood Res. Soc., 1988, vol. 34, no. 2, pp. 155-161.

102. Yoshiama A., Nonaka T., Kawakami H., Chou T-C., Tien H-J. J. Jap. Wood Res. Soc., 1988, vol. 34, no. 3, pp. $2755-2780$.

103. Yoshiama A., Chou T-C., Nonaka T., Kawakami H., Tien H-J. J. Jap. Wood Res. Soc., 1988, vol. 34, no. 8, pp. $702-706$.

104. Lalvani S.B., Rajagopal P. Holzforschung, 1993, vol. 47, issue 4, pp. 283-286.

105. Kovalenko E.I., Smirnov V.A., Shalimov V.N. Zhurnal prikladnoi khimii, 1977, vol. 50, no. 8, pp. 1741-1744. (in Russ.).

106. Anisimova M.I., Babkin V.A., Kozhevnikova L.G., Zaitseva L.A., Vasianovich G.P., Isakova N.V. Khimiia drevesiny, 1980, no. 2, pp. 72-77. (in Russ.).

107. Parpot P., Bettencourt A.P., Carvalho A.M., Belgsir E.M. J. Appl. Electrochem., 2000, vol. 30, pp. 727-731.

108. Moodley B., Mulholland D.A., Brookes H.C. Water SA, 2011, vol. 37, no. 1, pp. 33-40.

109. Smith C., Utley J.H.P. J. Appl. Electrochem., 1989, vol. 19, pp. 535-539.

110. Kovalenko E.I., Kotenko N.P., Smirnov V.A., Liashko O.V. Khimiia drevesiny, 1986, no. 5, pp. 66-72. (in Russ.).

111. Kovalenko E.I., Kotenko N.P., Smirnov V.A., Saratova L.A. Khimiia drevesiny, 1986, no. 6, pp. 98-101. (in Russ.).

112. Popova O.V. Nauchnye osnovy elektrokhimicheskogo modifitsirovaniia ligninov: avtoref. dis... dokt. tekh. nauk. [Scientific basis of electrochemical modification of lignin: the dissertation author's Doctor of Technical Sciences]. Saratov, 2006, 41 p. (in Russ.).

113. Kovalenko E.I., Kotenko N.P. Zhurnal prikladnoi khimii, 1990, vol. 63, no. 2, pp. 389-395. (in Russ.).

114. Demin V.A., Davydov V.D., Bogomolov B.D. Khimiia drevesiny, 1979, no. 2, pp. 41-44. (in Russ.).

115. Demin V.A., Bogomolov B.D., Karmanov A.P., Davydov V.D. Khimiia drevesiny, 1980, no. 4, pp. 82-84. (in Russ.).

116. Demin V.A., Davydov V.D., Bogomolov B.D. Elektrokhimicheskaia otbelka sul'fatnoi tselliulozy. [Electrochemical bleaching of kraft pulp]. Leningrad, 1982,. 135 p. (in Russ.).

117. Padtberg C., Kim H.-C., Mickel M., Bartling S., Hampp N. Tappi J., 2001, vol. 84, no. 4, pp. 68-69.

118. Hampp N., Bartling S., Kim H.-C., Mickel M. Electrochimica Acta, 2001, vol. 47, issue 5, pp. 799-805.

119. Mickel M., Kim H.-C., Hampp N. Green Chem., 2003, vol. 5, pp. 8-14. 
120. Bezuglyi V.D. Poliarografiia v khimii i tekhnologii polimerov. [Polarography in the Chemistry and Technology of Polymers]. Leningrad, 1968. 232 p. (in Russ.).

121. Metzger J.O., Bicke O., Faix O., Tuszynski W., Angermann R., Karas M., Strupat K. Angew. Chem. Int. Ed. Engl., 1992, vol. 31, no. 6, pp. 762-764.

122. Entelis S.G., Evreinov V.V., Kuzaev A.I. Reaktsionnosposobnye oligomery. [Reactive oligomers]. Moscow, 1985, 304 p. (in Russ.).

123. Vagin M.Yu., Trashin S.A., Karyakin A.A. Electrochem. Commun., 2006, vol. 8, issue 1, pp. 60-64.

124. Chen A., Rogers E.I., Compton R.G. Electroanalysis, 2010, vol. 22, issue 10, pp. 1037-1044.

125. Reichert E., Wintringer R., Volmer D.A., Hempelmann R. Phys. Chem. Chem. Phys., 2012, vol. 14, pp. 5214-5221.

Received October 1, 2013

Revised June 26, 2014 